\title{
Modeling and Design for a Direct Carbon Fuel Cell with Entrained Fuel and Oxidizer
}

\author{
Final Report
}

August 16, 2003 - November 15, 2004

\author{
Dr. Alan A. Kornhauser \\ Ritesh Agarwal \\ Report issued in April 2005 \\ DOE Contract no. DE-FG26-03NT41801
}

\author{
Department of Mechanical Engineering \\ Virginia Polytechnic Institute and State University \\ Blacksburg, VA 24061-0238
}




\section{Disclaimer}

"This report was prepared as an account of work sponsored by an agency of the United States Government. Neither the United States Government nor any agency thereof, nor any of their employees, makes any warranty, express or implied, or assumes any legal liability or responsibility for the accuracy, completeness, or usefulness of any information, apparatus, product, or process disclosed, or represents that its use would not infringe privately owned rights. Reference herein to any specific commercial product, process, or service by trade name, trademark, manufacturer, or otherwise does not necessarily constitute or imply its endorsement, recommendation, or favoring by the United States Government or any agency thereof. The views and opinions of authors expressed herein do not necessarily state or reflect those of the United States Government or any agency thereof." 


\section{Abstract}

The novel molten carbonate fuel cell design described in this report uses porous bed electrodes. Molten carbonate, with carbon fuel particles and oxidizer entrained, is circulated through the electrodes.

Carbon may be reacted directly, without gasification, in a molten carbonate fuel cell. The cathode reaction is $2 \mathrm{CO}_{2}+\mathrm{O}_{2}+4 \mathrm{e}^{-} \rightarrow 2 \mathrm{CO}_{3}^{=}$, while the anode reaction can be either $\mathrm{C}+2 \mathrm{CO}_{3}^{=} \rightarrow 3 \mathrm{CO}_{2}+4 \mathrm{e}^{-}$or $2 \mathrm{C}+\mathrm{CO}_{3}^{=} \rightarrow 3 \mathrm{CO}+2 \mathrm{e}^{-}$. The direct carbon fuel cell has an advantage over fuel cells using coal-derived synthesis gas in that it provides better overall efficiency and reduces equipment requirements. Also, the liquid electrolyte provides a means for transporting the solid carbon. The porous bed cell makes use of this carbon transport ability of the molten salt electrolyte.

A one-dimensional model has been developed for predicting the performance of this cell. For the cathode, dependent variables are superficial $\mathrm{O}_{2}$ and $\mathrm{CO}_{2}$ fluxes in the gas phase, superficial $\mathrm{O}_{2}$ and $\mathrm{CO}_{2}$ fluxes in the liquid phase, superficial current density through the electrolyte, and electrolyte potential. The variables are related by correlations, from the literature, for gas-liquid mass transfer, liquid-solid mass transfer, cathode current density, electrode overpotential, and resistivity of a liquid with entrained gas. For the anode, dependent variables are superficial $\mathrm{CO}_{2}$ flux in the gas phase, superficial $\mathrm{CO}_{2}$ flux in the liquid phase, superficial C flux, superficial current density through the electrolyte, and electrolyte potential. The same types of correlations relate the variables as in the cathode, with the addition of a correlation for resistivity of a fluidized bed. CO production is not considered, and axial dispersion is neglected.

The model shows behavior typical of porous bed electrodes used in electrochemical processes. Efficiency is comparable to that of membrane electrode fuel cells. Effective bed depths are on the order of 1-5 centimeter, giving power/volume lower than for membrane electrode cells. The porous bed design, however, uses less expensive materials and is more resistant to fouling by coal impurities.

The model will be used in the second phase of the project to design a laboratory-scale prototype cell. The prototype cell will demonstrate the concept and provide experimental data for improving the model. 


\section{Contents}

1 Introduction $\quad 1$

2 Executive Summary $\quad 4$

3 Chemical Kinetics and Mass Transfer Analysis $\quad 6$

3.1 Upflow in Packed Bed Cathode . . . . . . . . . . . . . . . . . . 6

3.1.1 Modeling Cathode Packed Bed through linear ODE's . . . . . . . . . 7

3.1.2 Initial Conditions for ODE's . . . . . . . . . . . . . . . . 8

3.1.3 Mass Transfer Equations for Packed Bed Cathode . . . . . . . . . . . 8

3.1.4 Molar Density equations: . . . . . . . . . . . . . . . . 9

3.1.5 Transfer Current Density Equations . . . . . . . . . . . . . . 11

3.2 Downflow in Packed Bed Anode . . . . . . . . . . . . . . . . . 12

3.2.1 Modeling Anode Packed Bed through linear ODE's . . . . . . . . . . 13

3.2.2 Initial Conditions for ODE's . . . . . . . . . . . . . . . . . . . 14

3.2.3 Mass Transfer Equations in Anode Packed Bed . . . . . . . . . . . . 15

3.2.4 Molar Density Equations . . . . . . . . . . . . . . . . 16

3.2.5 Transfer Current Density Equations . . . . . . . . . . . . . . . 18

4 Experimental $\quad 19$

4.1 Input Parameters . . . . . . . . . . . . . . . . . . . . . . . 19

4.2 Anode and Cathode Models . . . . . . . . . . . . . . . . . . . . 20

5 Results and Discussion $\quad 22$

5.1 Base Case Results . . . . . . . . . . . . . . . . . . . . 22

5.2 Parametric studies . . . . . . . . . . . . . . . . 26

5.2.1 Effect of cell temperature .................. . . 26

5.2.2 Effect of carbon loading . . . . . . . . . . . . . . . . 28

6 Conclusions $\quad 30$

$\begin{array}{lll}7 & \text { Future Work } & 32\end{array}$

$\begin{array}{ll}\text { Appendices } & 33\end{array}$

A Analysis of the Packed Bed Parameters 33

A.1 Calculation of Area per Unit Volume of the Packed Bed . . . . . . . . . . . . 33

A.2 Calculation of Volume fraction of Electrode . . . . . . . . . . . . . 33 
A.3 Calculation of Packed Bed Void Fraction . . . . . . . . . . . . . . 34

A.4 Calculation of equivalent packing diameter . . . . . . . . . . . 34

A.5 Model for finding carbon surface area per unit volume . . . . . . . . . . . 34

B Contact Resistance Model $\quad 36$

B.1 Bed Expansion Evaluation . . . . . . . . . . . . . . . . . . . . . 36

B.2 Resistivity Correlation . . . . . . . . . . . . . . . 36

$\begin{array}{ll}\text { C Open Circuit Potential } & 38\end{array}$

D Modified equations in Anode due to presence of both $\mathrm{CO}$ and $\mathrm{CO}_{2} \quad 39$

E Molten Salt Characteristics and Gas Properties variation with Tempera$\begin{array}{lr}\text { ture } T & 40\end{array}$

$\begin{array}{lrr}\text { F Energy Balance Paper } & 41\end{array}$ 


\section{List of Figures}

1 Schematic of the Packed Bed Direct Carbon Molten Carbonate Fuel Cell . . 2

2 Balance of Plant for the Direct Carbon Molten Carbonate Fuel Cell. . . . . . 3

3 Cathode Model showing the Dependent and Independent Variables. . . . . . 7

4 Carbon particle exchanging current with the bed. . . . . . . . . . . . 13

5 Anode Model showing the Dependent and Independent Variables. . . . . . . 14

6 Flow Chart for the ANODE model. . . . . . . . . . . . . . . . . . . . . 20

7 Flow Chart for the CATHODE model. . . . . . . . . . . . . . . . . 21

8 Overpotential losses in Cathode and Anode. . . . . . . . . . . . . . . . 22

9 Effect of Carbon Overfeed on the Voltage Drop due to Contact Resistance Losses in Anode. . . . . . . . . . . . . . . . . . . . . . . . . . 23

10 Power Density and Cell Voltage as against the Current Density. . . . . . . . 24

11 Variation in Current Density along the Bed Length in Anode and Cathode. . 25

12 Effect of cell temperature on the current density - voltage relationship. . . . 26

13 Effect of cell temperature on the current density - power density relationship. 27

14 Effect of carbon loading on the current density - voltage relationship. . . . . 28

15 Effect of carbon loading on the current density - power density relationship. 29

\section{List of Tables}

1 Various Correlations Used for the Cathode Packed Bed . . . . . . . . . . . . 10

2 Various Correlations Used for the Anode Packed Bed . . . . . . . . . . . . 17

3 Input Parameters for the Base Case . . . . . . . . . . . . . . . . . . . . . 19

A-1 Densities of various forms of carbon . . . . . . . . . . . . . . . . 36 


\title{
Nomenclature
}

\author{
Roman Letters
}

$A^{\prime \prime \prime} \quad$ area per unit volume $\quad \mathrm{m}^{-1}$

$x \quad$ bed depth m

D molecular diffusivity of solute $\mathrm{m}^{2} \mathrm{~s}^{-1}$

$d_{\mathrm{C}} \quad$ diameter of the carbon particle $\mathrm{m}$

$D_{\mathrm{h}} \quad$ diameter of the hole within packing m

$d_{\mathrm{p}} \quad$ packing diameter of the bed $\mathrm{m}$

$\Delta P / \Delta Z$ pressure gradient within the reactor bed $\quad \mathrm{N} \mathrm{m}^{-3}$

$d_{\mathrm{p}}^{\prime} \quad$ specific surface diameter $\mathrm{m}$

$E \quad$ rate of energy dissipation per unit mass of fluid $\mathrm{m}^{2} \mathrm{~s}^{-3}$

F Faraday's constant $(=96487) \quad$ Coulombs/gmol e ${ }^{-}$

$f \quad$ friction factor

$\mathrm{Fr} \quad$ Froude number

G Gibb's Energy

$g \quad$ acceleration of gravity $(=9.81) \quad \mathrm{m} \mathrm{s}^{-2}$

$H \quad$ Henry's Law constant $\quad \mathrm{kmol} \mathrm{m}^{-3} \mathrm{kPa}^{-1}$

$H_{\mathrm{b}} \quad$ height of the bed $\mathrm{m}$

$h_{\mathrm{b}} \quad$ interspacing between the packing $\mathrm{m}$

$h \quad$ hold-up

$i \quad$ current density $\mathrm{Amps} \mathrm{m}^{-2}$

$\mathrm{k}, \mathrm{K}$ mass transfer coefficient $\mathrm{m} \mathrm{s}^{-1}$

$K_{\text {salt }} \quad$ salt conductivity $\quad \Omega \mathrm{m}$

$L_{\mathrm{b}} \quad$ length of the bed m

$M \quad$ molecular weight $\quad \mathrm{kg} \mathrm{kmol}^{-1}$

$n_{\text {part }} \quad$ carbon moles per particle

$\dot{N}^{\prime \prime} \quad$ particle flux

$N_{\text {hole }} \quad$ number of holes in the packing

$\dot{n}_{\mathrm{i}, \mathrm{p}, \mathrm{r}}^{\prime \prime} \quad$ mole flux of solute $\mathrm{i}$ in phase $\mathrm{p}$ of the packed bed $\mathrm{kmol} \mathrm{m}^{-2} \mathrm{sec}^{-1}$

reactor, $r$

$N^{\prime \prime \prime} \quad$ particle per unit volume

$O A \quad$ open area of the packing

$P \quad$ pressure, partial pressure $\quad \mathrm{kPa}$

$\begin{array}{lll}P_{\text {atm }} \quad \text { atmospheric pressure }(=101.325) & \mathrm{kPa}\end{array}$ 


$\begin{array}{lll}R & \text { Ohmic Resistance } & \Omega \\ \bar{R} & \text { universal gas constant }(=8.3144) & \mathrm{kJ} \mathrm{kmol}^{-1} \mathrm{~K}^{-1} \\ R e & \text { Reynolds number } & \\ \overline{R e} & \text { Reynolds number based on dissipation } & \\ S c & \text { Schmidt number } & \\ S h & \text { Sherwood number } & \\ S & \text { surface area of the packing bed } & \mathrm{m}^{2} \\ T & \text { cell temperature } & \mathrm{K} \\ t & \text { thickness of the packing } & \mathrm{m} \\ U & \text { true velocity } & \mathrm{ms}^{-1} \\ U_{0} & \text { superficial velocity } & \mathrm{m} \mathrm{s}^{-1} \\ V & \text { voltage } & \mathrm{Vollts}^{2} \\ V_{\text {cell }} & \text { cell voltage } & \mathrm{Vollts} \\ V_{\mathrm{oc}} & \text { open-circuit voltage } & \mathrm{Volls}^{2} \\ V_{p} & \text { volume of the packing bed } & \mathrm{m}^{3} \\ W_{\mathrm{b}} & \text { width of the bed } & \mathrm{m}\end{array}$

\section{Greek Letters}

$\begin{array}{lll}\alpha & \text { charge transfer coefficient } & \\ \alpha_{\mathrm{s}} & \text { volume fraction carbon } & \\ \beta & \text { voltage distribution factor } & \\ \delta & \text { thickness of the liquid layer on the packing } & \mathrm{m} \\ \eta & \text { chemical overpotential } & \text { Volts } \\ \gamma & \text { overfeed } & \\ \nu & \text { kinematic viscosity } & \mathrm{m}^{2} \mathrm{~s}^{-1} \\ \phi_{\mathrm{c}} & \text { Carman surface factor } & \\ \rho & \text { density } & \mathrm{kg} \mathrm{m}^{-3} \\ \bar{\rho} & \text { molar density } & \mathrm{kmol} \mathrm{m}^{-3} \\ \zeta & \text { volume fraction of electrode } & \end{array}$

\section{Subscripts}
a anode
b bubble
C carbon 


$\begin{array}{ll}\text { c } & \text { cathode } \\ \text { G } & \text { gas phase } \\ \text { i } & \text { solute } \\ \text { init } & \text { initial } \\ \text { LG } & \text { liquid and gas phases flowing simultaneously and } \\ & \text { concurrently } \\ \text { L } & \text { liquid phase } \\ \text { LS } & \text { liquid and solid phases together } \\ \text { rev } & \text { reversible } \\ \text { S } & \text { solid phase } \\ \text { S } & \text { surface }\end{array}$




\section{Introduction}

Electrochemical conversion of coal has been considered for more than 100 years. Most current fuel cell research is directed toward hydrogen (or other gas) fueled cells, but there has recently been a renewed interest in cells fueled with solid carbon.

The major motivation for recent work with direct carbon cells has been higher theoretical energy efficiency compared to thermal conversion processes [1]. Despite the difficulties inherent in building a solid-fed fuel cell, a direct carbon fuel cell offers distinct thermodynamic advantages over other options for utility-scale power generation. Steinberg et al [2] projected overall first-law efficiencies (based on higher heating value) of $68 \%$ for power plants using direct carbon fuel cells, as compared $50 \%$ for gasification combined cycle plants and $38 \%$ for conventional Rankine-cycle plants. Projected capital costs for the three types of plants were equal.

The two main candidates for direct carbon fuel cells are solid oxide and molten carbonate cells. The molten carbonate cell appears the more attractive of the two because it is easier to feed a solid fuel to a liquid electrolyte than to a solid electrolyte and because molten carbonate cells produce relatively more $\mathrm{CO}_{2}$ relative to CO. During 1970s, the workers at Stanford Research Institute investigated direct-carbon molten carbonate cells [3] and concluded that molten carbonate fuel cells produce more $\mathrm{CO}_{2}$ (as opposed to $\mathrm{CO}$ ) than predicted by thermodynamic equilibrium. Although the reasons for the higher $\mathrm{CO}_{2}$ levels are not understood, they will allow operation at high temperatures which give high reaction rates but also give high equilibrium $\mathrm{CO}$.

Various researchers have proposed designs based on direct carbon concepts. Some used solid oxide electrolytes: Gür and Huggins [4] heated carbon to vaporize it so that it could react on a solid oxide, while Horita et al [5] built a cell in which carbon powder was mixed with carbide powder in contact with solid oxide. Others used molten carbonates: Weaver et al [3] proposed a plant in which coal would be formed into solid anodes and fed into a molten carbonate melt. Cooper [6] and his co-workers supplied a paste of carbon fuel granules in a molten salt to the anode grid of a molten carbonate cell. Vutetakis et al [7] oxidized slurries of coal in molten carbonate melts.

This report summarizes the initial phase of the investigation done on the feasibility of a novel direct carbon molten carbonate fuel cell. The report describes the mass transfer and 
electrochemical analyses inside the cathode and anode. It is based on the preliminary cell design shown in figure 1.

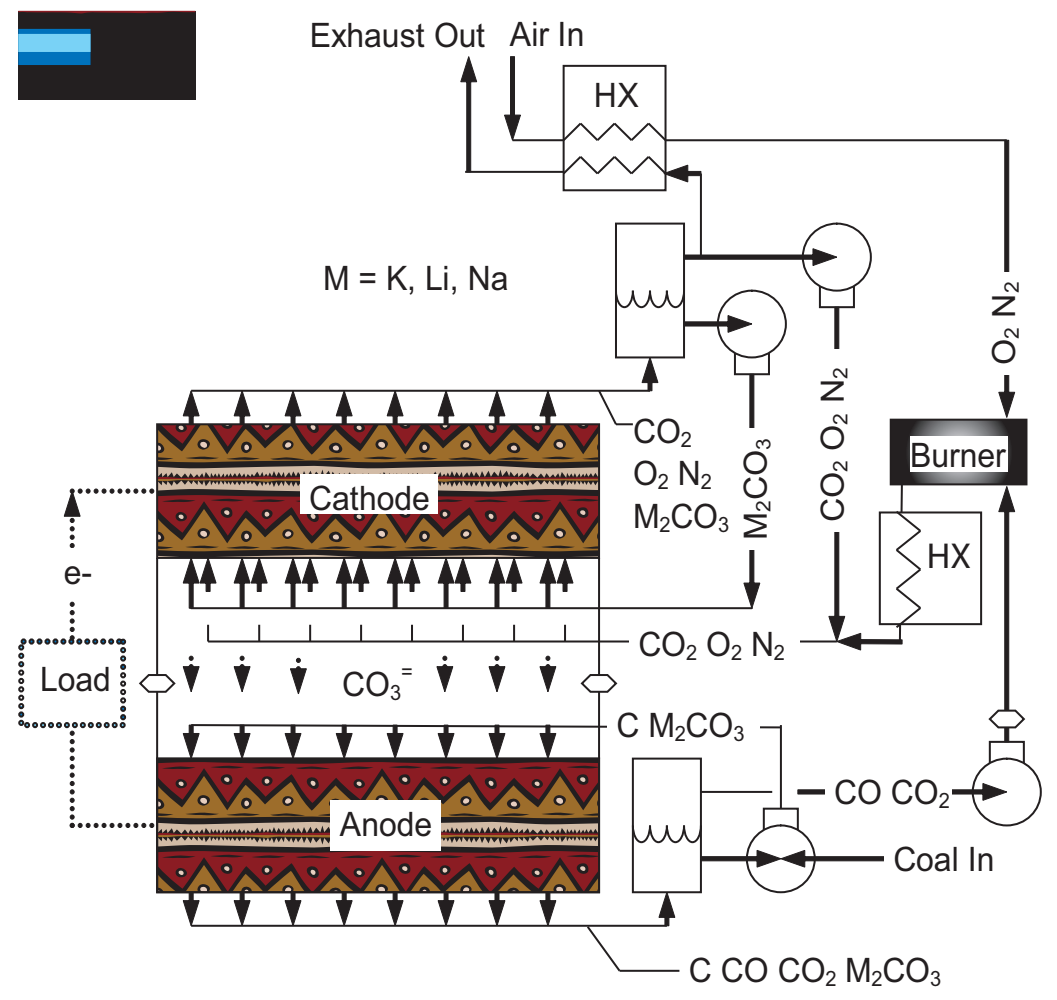

Figure 1: Schematic of the Packed Bed Direct Carbon Molten Carbonate Fuel Cell

The cell investigated here is based largely on the work of Vutetakis et al, but it also has roots in those industrial electrolysis technologies which use porous bed electrodes [8]. As shown schematically in figure 1, both the anode and the cathode are electrically connected porous beds. Molten carbonate salt, with particles of carbon entrained, is pumped downward through the anode bed. It reacts with $\mathrm{CO}_{3}^{=}$ions diffusing from the cathode to form $\mathrm{CO}$ and $\mathrm{CO}_{2}$ while sending electrons to the load. Downward velocity of the salt is adequate to ensure that both carbon and evolved gases move downwards. Salt, evolved gases, and overfed carbon exit the bottom of the anode and gases are separated from the liquid/solid slurry. The slurry is enriched with more carbon and recirculated through the anode, while the evolved gases are used to supply $\mathrm{CO}_{2}$ to the cathode.

Because this cell has a continuous flow of salt through the anode, fuel contaminants will be carried off with the flow. They can then be removed by a sidestream treatment plant such as that described by Weaver et al [9]. Unlike porous-membrane fuel cells, the porous 
bed cell can be effectively scaled up to large size, so that a utility-scale plant could be made of a relative small number of large cells. The technology is more akin to that of an electrochemical plant than to that of a storage battery.

An overall fuel cell mass/energy balance on the cell and its auxiliaries was presented by the authors in [10], a reprint of which has been included as Appendix E. The arrangement of burner and heat exchangers considered as balance-of-plant for this analysis shown in figure 2. The most important finding in the mass/energy balance analysis of the cell was that the $\mathrm{CO} / \mathrm{CO}_{2}$ ratio is an important parameter for determining cell performance. Another finding was that temperature, if decoupled from $\mathrm{CO} / \mathrm{CO}_{2}$ ratio, has a relatively small effect on first law efficiency. The most important effects of temperature will likely be those on reaction rates, on materials requirements, and on air preheater size.

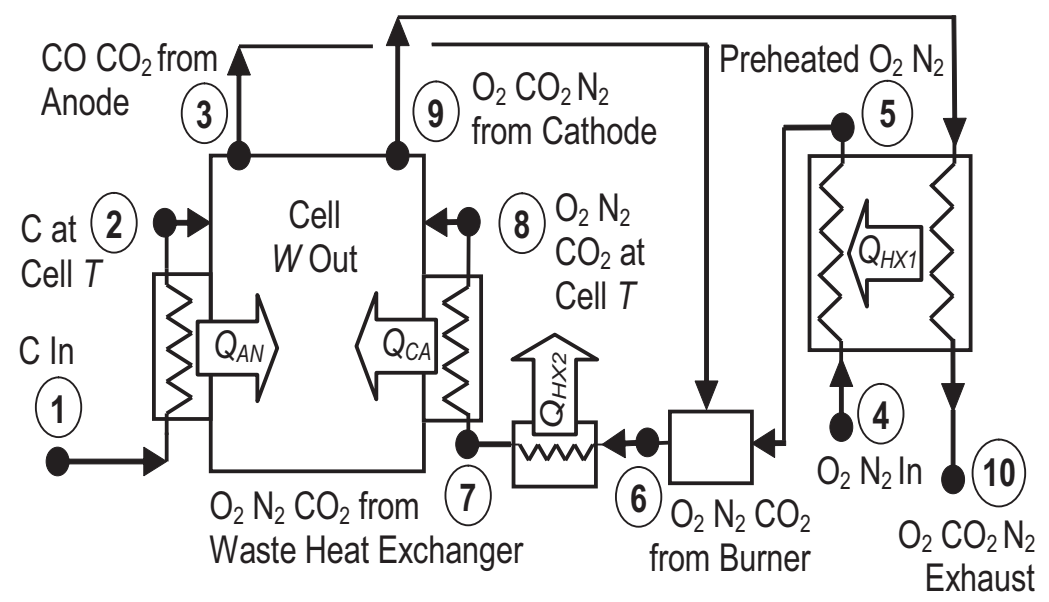

Figure 2: Balance of Plant for the Direct Carbon Molten Carbonate Fuel Cell. 


\section{Executive Summary}

The novel molten carbonate fuel cell design described in this report uses porous bed electrodes. The electrolyte used here, a ternary eutectic mixture of $(\mathrm{Li}-\mathrm{Na}-\mathrm{K})_{2} \mathrm{CO}_{3}$, is entrained with the carbon fuel particles and the oxidizer air and circulated through the packed bed anode and cathode. The cathode reaction is $2 \mathrm{CO}_{2}+\mathrm{O}_{2}+4 \mathrm{e}^{-} \rightarrow 2 \mathrm{CO}_{3}^{=}$, while the anode reaction can be either $\mathrm{C}+2 \mathrm{CO}_{3}^{=} \rightarrow 3 \mathrm{CO}_{2}+4 \mathrm{e}^{-}$or $2 \mathrm{C}+\mathrm{CO}_{3}^{=} \rightarrow 3 \mathrm{CO}+2 \mathrm{e}^{-}$depending upon the equilibrium. Carbon may be reacted directly, without gasification, in a molten carbonate fuel cell. The direct carbon fuel cell has an advantage over fuel cells using coal-derived synthesis gas in that it provides better overall efficiency and reduces equipment requirements. Also, the liquid electrolyte provides a means for transporting the solid carbon. The porous bed cell makes use of this carbon transport ability of the molten salt electrolyte.

An energy balance for the cell and its auxiliaries has been done during the initial phase of this project. The design calls for the $\mathrm{CO}-\mathrm{CO}_{2}$ mixture leaving the anode to be burned to supply an $\mathrm{O}_{2}-\mathrm{N}_{2}-\mathrm{CO}_{2}$ mixture to the cathode. Two heat exchangers are employed: an air preheater cooling the exhaust and a waste heat exchanger cooling the gases entering the cathode. Results show that $\mathrm{CO} / \mathrm{CO}_{2}$ ratio is the most important parameter for determining performance. Experiments by others have shown that $\mathrm{CO}_{2}$ concentrations exceed those predicted by Boudouard equilibrium, and therefore a useful alternate model is clearly necessary for good cell design and accurate prediction of cell performance. Temperature, if decoupled from $\mathrm{CO} / \mathrm{CO}_{2}$ ratio, has a relatively small effect on first law efficiency. Increasing cell temperature generally increases work output slightly and also increases the value of the waste heat. The most important effects of temperature will likely be those on reaction rates, on materials requirements, and on air preheater size. For other conditions ideal, plant efficiency varies from $\sim 90 \%$ for pure $\mathrm{CO}_{2}$ to $\sim 20 \%$ for pure $\mathrm{CO}$. The main effect of decreasing internal cell efficiency is to lower power output and increase waste heat rejection.

During the second phase of this project, a one-dimensional model has been developed for predicting the performance of the cell as described above. The model equations are developed by considering a bubbly flow within the packed bed anode and cathode. Due to this bubbly flow there is a mass transfer of gases like $\mathrm{CO}_{2}$, and $\mathrm{O}_{2}$ from the gas bubble phase

to the liquid phase and from liquid phase onto the surface of the current collector. For the cathode, dependent variables are superficial $\mathrm{O}_{2}$ and $\mathrm{CO}_{2}$ fluxes in the gas phase, superficial $\mathrm{O}_{2}$ and $\mathrm{CO}_{2}$ fluxes in the liquid phase, superficial current density through the electrolyte, and electrolyte potential. The variables are related by correlations, from the literature, for 
gas-liquid mass transfer, liquid-solid mass transfer, cathode current density, electrode overpotential, and resistivity of a liquid with entrained gas. For the anode, dependent variables are superficial $\mathrm{CO}_{2}$ flux in the gas phase, superficial $\mathrm{CO}_{2}$ flux in the liquid phase, superficial C flux, superficial current density through the electrolyte, and electrolyte potential. The same types of correlations relate the variables as in the cathode, with the addition of a correlation for resistivity of a fluidized bed. CO production is not considered, and axial dispersion is neglected.

The model shows behavior typical of porous bed electrodes used in electrochemical processes. Effective bed depths are on the order of one to five centimeter, giving an efficiency and energy/volume competitive with membrane electrode fuel cells while allowing much higher output from a single cell. The model is now being used in the second phase of the project to design a laboratory-scale prototype cell to demonstrate the concept. 


\section{Chemical Kinetics and Mass Transfer Analysis}

Analysis is based on the packed bed column design shown in figure 1. The equation set for the mass transfer processes taking place within the packed bed is based on the work of Herrmann and Emig [11]. Axial diffusion has not been considered, but is believed to be negligible. The reactions taking place within the cell are:

At the anode:

$$
\begin{aligned}
& \mathrm{C}+2 \mathrm{CO}_{3}^{=} \rightarrow 3 \mathrm{CO}_{2}+4 e^{-} \\
& 2 \mathrm{C}+\mathrm{CO}_{3}^{=} \rightarrow 3 \mathrm{CO}+2 e^{-}
\end{aligned}
$$

At the cathode:

$$
\mathrm{O}_{2}+2 \mathrm{CO}_{2}+4 e^{-} \rightarrow 2 \mathrm{CO}_{3}^{=}
$$

The production of $\mathrm{CO}$ in the anode has been neglected because it is believed to be low and because no model (besides chemical equilibrium, known to be inaccurate) for CO production has been developed.

\subsection{Upflow in Packed Bed Cathode}

The reaction taking place at the cathode is:

$$
\mathrm{O}_{2}+2 \mathrm{CO}_{2}+4 e^{-} \rightarrow 2 \mathrm{CO}_{3}^{=}
$$

The packed bed cathode has a structure that allows flow of gases and electrolyte while the cathode structure remains electrically connected. The concept for cathode design is a stack of screens or perforated plates, spaced and supported by vertical rods that double as electron conductors. The outer electrode vessel is in contact with the electrode plates and thus forms part of the electrode, but its contribution to the reaction will be small and has been neglected. The anode and cathode vessels are separated by an electrically insulated joint. The molten salt electrolyte along with the $\mathrm{CO}_{2}$ and the air is pumped upward through the cathode packed bed. The reaction of $\mathrm{CO}_{2}$ and $\mathrm{O}_{2}$ produces carbonate ion $\mathrm{CO}_{3}^{=}$which travels down by ionic conduction towards the anode. The gases $\mathrm{CO}_{2}$ and $\mathrm{O}_{2}$ diffuse through the molten salt to reach the electrode reaction sites where the reaction takes place. There is mass transfer of $\mathrm{CO}_{2}$ and $\mathrm{O}_{2}$ occurring from the gas bubble to the bulk electrolyte and mass transfer of $\mathrm{CO}_{2}$ and $\mathrm{O}_{2}$ from the bulk electrolyte to the electrode surface.

The model for the cathode is written with distance into the cathode as independent variable and with six dependent variables: molar $\mathrm{CO}_{2}$ fluxes in the gas and liquid phases, molar 
$\mathrm{O}_{2}$ fluxes in the gas and liquid phases, $\mathrm{CO}_{3}^{=}$current density, and voltage. Figure 3 shows how the dependent variables and independent variables are setup within the cathode. The

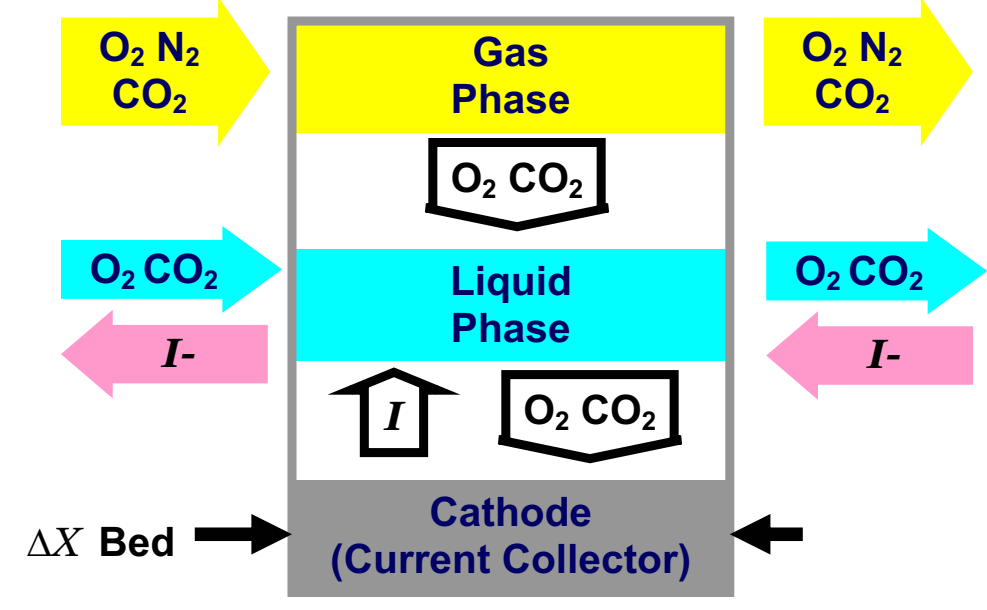

Figure 3: Cathode Model showing the Dependent and Independent Variables.

following sections present the differential equation set for these variables and the correlations used in the differential equations. The correlations are also presented in Table 2.

\subsubsection{Modeling Cathode Packed Bed through linear ODE's}

The cathode model consists of six simultaneous first-order ordinary differential equations. $\mathrm{CO}_{2}$ and $\mathrm{O}_{2}$ in gas phase:

$$
\begin{aligned}
\frac{d \dot{n}_{\mathrm{co}_{2}, \mathrm{~g}, \mathrm{c}}^{\prime \prime}}{d x_{\mathrm{c}}} & =-K_{\mathrm{co}_{2}, \mathrm{~g}-\ell, \mathrm{c}} A_{\mathrm{b}, \mathrm{c}}^{\prime \prime \prime}\left(\frac{\bar{R} T}{H_{\mathrm{co}_{2}}} \bar{\rho}_{\mathrm{co}_{2}, \mathrm{~g}, \mathrm{c}}-\bar{\rho}_{\mathrm{co}_{2}, \ell, \mathrm{c}}\right) \\
\frac{d \dot{n}_{\mathrm{o}_{2}, \mathrm{~g}, \mathrm{c}}^{\prime \prime}}{d x_{\mathrm{c}}} & =-K_{\mathrm{o}_{2}, \mathrm{~g}-\ell, \mathrm{c}} A_{\mathrm{b}, \mathrm{c}}^{\prime \prime \prime}\left(\frac{\bar{R} T}{H_{\mathrm{o}_{2}}} \bar{\rho}_{\mathrm{o}_{2}, \mathrm{~g}, \mathrm{c}}-\bar{\rho}_{\mathrm{o}_{2}, \ell, \mathrm{c}}\right)
\end{aligned}
$$

$\mathrm{CO}_{2}$ and $\mathrm{O}_{2}$ in liquid phase:

$$
\begin{aligned}
\frac{d \dot{n}_{\mathrm{co} 2}^{\prime \prime} \ell, \mathrm{c}}{d x_{\mathrm{c}}} & =K_{\mathrm{co} 2, \mathrm{~g}-\ell, \mathrm{c}} A_{\mathrm{b}, \mathrm{c}}^{\prime \prime \prime}\left(\frac{\bar{R} T}{H_{\mathrm{co}_{2}}} \bar{\rho}_{\mathrm{co} 2, \mathrm{~g}, \mathrm{c}}-\bar{\rho}_{\mathrm{co} 2, \ell, \mathrm{c}}\right)-\left(\frac{A_{\mathrm{s}, \mathrm{c}}^{\prime \prime \prime} i_{\mathrm{s}, \mathrm{c}}^{\prime \prime}}{2 F}\right) \\
\frac{d \dot{n}_{\mathrm{o} 2}^{\prime \prime}, \ell \mathrm{c}}{d x_{\mathrm{c}}} & =K_{\mathrm{o}_{2}, \mathrm{~g}-\ell, \mathrm{c}} A_{\mathrm{b}, \mathrm{c}}^{\prime \prime \prime}\left(\frac{\bar{R} T}{H_{\mathrm{o}_{2}}} \bar{\rho}_{\mathrm{o}_{2}, \mathrm{~g}, \mathrm{c}}-\bar{\rho}_{\mathrm{o}_{2}, \ell, \mathrm{c}}\right)-\left(\frac{A_{\mathrm{s}, \mathrm{c}}^{\prime \prime \prime} i_{\mathrm{s}, \mathrm{c}}^{\prime \prime}}{4 F}\right)
\end{aligned}
$$

$\Delta \mathrm{V}$ in molten salt:

$$
\frac{d V_{\mathrm{c}}}{d x_{\mathrm{c}}}=-i_{\mathrm{c}}^{\prime \prime} R_{\mathrm{c}}
$$


Ionic current flux perpendicular to face of bed:

$$
\frac{d i_{\mathrm{c}}^{\prime \prime}}{d x_{\mathrm{c}}}=i_{\mathrm{s}, \mathrm{c}}^{\prime \prime} A_{\mathrm{s}, \mathrm{c}}^{\prime \prime \prime}
$$

\subsubsection{Initial Conditions for ODE's}

If we consider an initial current density of $i_{0}^{\prime \prime}$ which is fed to both anode and cathode at the starting of the bed, and $\gamma_{\mathrm{Co}_{2}}$ and $\gamma_{\mathrm{o}_{2}}$ be the respective overfeed factors for $\mathrm{CO}_{2}$ and $\mathrm{O}_{2}$ then the initial conditions for mole fluxes of $\mathrm{CO}_{2}$ and $\mathrm{O}_{2}$ in the cathode gas phase are:

$$
\begin{gathered}
\dot{n}_{\mathrm{co}_{2}, \mathrm{~g}, \mathrm{c}}^{\prime \prime}(0)=\gamma_{\mathrm{co}_{2}} \cdot \frac{i_{0}^{\prime \prime}}{2 F} \\
\dot{n}_{\mathrm{o}_{2}, \mathrm{~g}, \mathrm{c}}^{\prime \prime}(0)=\gamma_{\mathrm{o}_{2}} \cdot \frac{i_{0}^{\prime \prime}}{4 F}
\end{gathered}
$$

The initial conditions for dissolved gas mole flux in the liquid phase are based on the liquid salt superficial velocity and the assumption that the salt is saturated with gases at the appropriate partial pressures:

$$
\begin{aligned}
& \dot{n}_{\mathrm{co}_{2}, \ell, \mathrm{c}}^{\prime \prime}(0)=\left[\frac{\dot{n}_{\mathrm{co}_{2}, \mathrm{~g}, \mathrm{c}}^{\prime \prime}(0)}{\dot{n}_{\mathrm{co}_{2}, \mathrm{~g}, \mathrm{c}}^{\prime \prime}(0)+\dot{n}_{\mathrm{o}_{2}, \mathrm{~g}, \mathrm{c}}^{\prime \prime}(0)}\right] P_{\mathrm{atm}} H_{\mathrm{co}_{2}} U_{\mathrm{oL}, \mathrm{c}} \\
& \dot{n}_{\mathrm{o}_{2}, \ell, \mathrm{c}}^{\prime \prime}(0)=\left[\frac{\dot{n}_{\mathrm{o}_{2}, \mathrm{~g}, \mathrm{c}}^{\prime \prime}(0)}{\dot{n}_{\mathrm{co}_{2}, \mathrm{~g}, \mathrm{c}}^{\prime \prime}(0)+\dot{n}_{\mathrm{o}_{2}, \mathrm{~g}, \mathrm{c}}^{\prime \prime}(0)}\right] P_{\mathrm{atm}} H_{\mathrm{o}_{2}} U_{\mathrm{oL}, \mathrm{c}}
\end{aligned}
$$

The initial condition for voltage is based on an assumed division of available chemical potential between the anode and the cathode:

$$
V_{\mathrm{c}}(0)=(1-\beta) \cdot\left(V_{\mathrm{oc}}-V_{\text {cell }}\right)
$$

The initial condition for ionic current flux is the cell current density based on face area:

$$
i_{\mathrm{c}}^{\prime \prime}(0)=i_{0}^{\prime \prime}
$$

\subsubsection{Mass Transfer Equations for Packed Bed Cathode}

The correlations to determine gas, liquid and solid side mass transfer coefficients for the upflow in the packed bed cathode are tabulated in Table 1.

The area for gas-liquid mass transfer is included as part of those correlations and is 
calculated in appendix A. The superficial velocities used in the correlations are all in $\mathrm{m} / \mathrm{sec}$. $\mathrm{U}_{\mathrm{oL}}$, the molten salt superficial velocity, is an input parameter and can be set to any feasible value within the range specified by the correlation. $U_{0 G}$ is determined from gas flux and ideal gas density,

$$
U_{\mathrm{oG}}=\left(\dot{n}_{\mathrm{co} 2, \mathrm{~g}, \mathrm{c}}^{\prime \prime}+4.76 \dot{n}_{\mathrm{o} 2, \mathrm{~g}, \mathrm{c}}^{\prime \prime}+\dot{n}_{\mathrm{n} 2, \mathrm{~g}, \mathrm{c}}^{\prime \prime}(0)\right) \frac{\bar{R} T}{P_{\mathrm{atm}}}
$$

where the molar fluxes of $\mathrm{CO}_{2}\left(\dot{n}_{\mathrm{co}_{2}, \mathrm{~g}, \mathrm{c}}^{\prime \prime}\right)$ and $\mathrm{O}_{2}\left(\dot{n}_{\mathrm{O}_{2}, \mathrm{~g}, \mathrm{c}}^{\prime \prime}\right)$ in the gas phase, are determined from the solution of the differential equations and the initial molar flux of $\mathrm{N}_{2}\left(\dot{n}_{\mathrm{n}_{2}, \mathrm{~g}, \mathrm{c}}^{\prime \prime}(0)\right)$ is found out from the initial conditions.

The net Gas-Liquid Mass Transfer Coefficient is obtained by combining gas-side coefficients, liquid-side coefficients, and Henrys Law constants,

$$
K_{\mathrm{i}, \mathrm{g}-\ell, \mathrm{c}} A_{\mathrm{b}, \mathrm{i}, \mathrm{c}}^{\prime \prime \prime}=\frac{1}{\left(1 / k_{\mathrm{L}} A_{b}^{\prime \prime \prime}+1 / k_{\mathrm{G}} A_{b}^{\prime \prime \prime}\right)}
$$

The Gas-Liquid Mass Transfer Coefficients for each gas, $\left(K_{\mathrm{co}_{2}, \mathrm{~g}-\ell, \mathrm{c}} A_{\mathrm{b}_{\mathrm{b}, \mathrm{c}}, \mathrm{c}}^{\prime \prime \prime}\right)$ and $\left(K_{\mathrm{O}_{2}, \mathrm{~g}-\ell, \mathrm{c}} A_{\mathrm{b}, \mathrm{O}_{2}, \mathrm{c}}^{\prime \prime \prime}\right)$ for $\mathrm{CO}_{2}$ and $\mathrm{O}_{2}$ respectively, can then be found easily from the individual gas properties.

The Liquid-solid Mass Transfer coefficient in the cathode can be determined from the Sherwood number in Table 1 using

$$
K_{\mathrm{s}}=\frac{S h D}{d_{\mathrm{e}} / 2}
$$

Here $\mathrm{D}$ is the molecular diffusivity of the solute $\left(\mathrm{CO}_{2}\right.$ or $\left.\mathrm{O}_{2}\right)$ in the molten salt.

According to the Bruggeman equation in [16], the resistivity of a bed of mixed materials depends on the resistivity of both materials. In the case of the cathode bed, however, the conductivity of the gas phase is negligible relative to that of the molten salt. While the solid cathode bed material is electronically conductive, it has no ionic conductivity. This gives us the simplified version of the Bruggeman equation in Table 1. In the correlation, $\epsilon_{g}$ is a combination of solid volume fraction and gas volume fraction, and so is determined from the gas holdup and the known bed properties. Correlations for $\mathrm{K}_{\text {salt }}$ as a function of temperature and composition are given in the Appendix.

\subsubsection{Molar Density equations:}

Molar density of $\mathrm{CO}_{2}$ in gas phase is calculated from the ideal gas law and the mole fraction $\mathrm{CO}_{2}$. The molar density of $\mathrm{CO}_{2}$ the liquid phase is calculated from mole fraction $\mathrm{CO}_{2}$ and 
Table 1: Various Correlations Used for the Cathode Packed Bed

\begin{tabular}{|c|c|c|c|c|}
\hline Parameter & Description & Correlation & Remarks & References \\
\hline$h_{\mathrm{G}}, h_{\mathrm{L}}$ & Holdups & $h_{\mathrm{G}}=\frac{1}{1+4.33\left(100 \times U_{0 \mathrm{~L}}\right)^{-0.433}\left(\frac{U_{\mathrm{OL}}}{U_{0 \mathrm{G}}}\right)^{0.563}}$ & $h_{\mathrm{L}}=1-h_{\mathrm{G}}$ & {$[12]$} \\
\hline \multirow[t]{2}{*}{$f_{\mathrm{LG}}$} & Two-phase friction factor & $f_{\mathrm{LG}}=\exp \left[8.0-1.12 \log \bar{Z}-0.0769(\log \bar{Z})^{2}+0.0152(\log \bar{Z})^{3}\right]$ & $\bar{Z}=\frac{R e_{\mathrm{G}}^{1.167}}{R e_{\mathrm{L}}^{0.767}}$ & {$[13]$} \\
\hline & & $\begin{array}{l}\text { where } R e_{\mathrm{G}}=\frac{U_{0 \mathrm{G}} d_{p}}{\nu_{\mathrm{G}}} \text { and } R e_{\mathrm{L}}=\frac{U_{0 \mathrm{~L}} d_{p}}{\nu_{\mathrm{L}}} \\
d_{\mathrm{e}}, \epsilon \text { given from appendix A.4 }\end{array}$ & $d_{\mathrm{p}}=\frac{3}{2} d_{\mathrm{e}} \frac{1-\epsilon}{\epsilon}$ & \\
\hline$k_{\mathrm{L}} A_{b}^{\prime \prime \prime}$ & Liquid side mass transfer coefficient & $k_{\mathrm{L}} A_{b}^{\prime \prime \prime}=0.12\left[\frac{U_{0 \mathrm{~L}}}{47.88}\left(\frac{\Delta P}{\Delta Z}\right)_{\mathrm{LG}}\right]^{0.5}$ & $\left(\frac{\Delta P}{\Delta Z}\right)_{\mathrm{LG}}=\frac{2 \rho_{\mathrm{G}} f_{\mathrm{LG}} U_{0 \mathrm{G}}^{2}}{d_{\mathrm{e}}}$ & {$[13,14]$} \\
\hline$k_{\mathrm{G}} A_{b}^{\prime \prime \prime}$ & Gas side mass transfer coefficient & $k_{\mathrm{G}} A_{b}^{\prime \prime \prime}=2+0.91\left[\frac{U_{0 \mathrm{~L}}}{47.88}\left(\frac{\Delta P}{\Delta Z}\right)_{\mathrm{LG}}\right]^{2 / 3}$ & & {$[14]$} \\
\hline \multirow[t]{3}{*}{$S h$} & Sherwood number & $S h=3.02\left(0.7+0.12\left[\frac{U_{\mathrm{G}}\left(1-h_{\mathrm{G}}\right)}{U_{\mathrm{L}} h_{\mathrm{G}}}\right]^{0.62}\right)\left(\frac{R e_{\mathrm{L}}^{*} S_{\mathrm{c}} d_{\mathrm{e}}}{\delta}\right)^{1 / 3}$ & $U_{\mathrm{L}}=U_{0 \mathrm{~L}} /\left(1-\zeta_{\mathrm{c}}\right)$ & {$[15]$} \\
\hline & & where $R e_{\mathrm{L}}^{*}=\frac{U_{\mathrm{L}} d_{\mathrm{e}}}{2 \nu_{\mathrm{L}}\left(1-h_{\mathrm{G}}\right)}$ and $\delta=0.15 d_{\mathrm{p}}\left(\frac{U_{\mathrm{G}}^{2}}{g d_{\mathrm{p}}}\right)^{-0.1}$ & $U_{\mathrm{G}}=U_{0 \mathrm{G}} /\left(1-\zeta_{\mathrm{c}}\right)$ & \\
\hline & & where $d_{\mathrm{p}}=\frac{3}{2} d_{\mathrm{e}} \frac{1-\epsilon_{o}}{\epsilon_{o}}, S_{\mathrm{c}}=\frac{\nu_{\mathrm{L}}}{D}$ & and $\epsilon_{o}=1-\frac{\pi}{3 \sqrt{2}}$ for $\mathrm{HCP}$ & \\
\hline$R_{\mathrm{c}}$ & Resistivity & $R_{\mathrm{c}}=\frac{1}{K_{\mathrm{salt}}}\left(1-\epsilon_{\mathrm{g}, \mathrm{c}}\right)^{-3 / 2}$ & $\epsilon_{\mathrm{g}, \mathrm{c}}=h_{\mathrm{G}}\left(1-\zeta_{\mathrm{c}}\right)+\zeta_{\mathrm{c}}$ & {$[16]$} \\
\hline
\end{tabular}


salt density. Units are $\mathrm{kmol} / \mathrm{m}^{3}$ :

$$
\begin{aligned}
& \bar{\rho}_{\mathrm{co}_{2}, \mathrm{~g}, \mathrm{c}}=\left(\frac{\dot{n}_{\mathrm{co}_{2}, \mathrm{~g}, \mathrm{c}}^{\prime \prime}}{\dot{n}_{\mathrm{co}_{2}, \mathrm{~g}, \mathrm{c}}^{\prime \prime}+4.76 \dot{n}_{\mathrm{o}_{2}, \mathrm{~g}, \mathrm{c}}^{\prime \prime}}\right)\left(\frac{101.325}{\bar{R} T}\right) \\
& \bar{\rho}_{\mathrm{co}_{2}, \ell, \mathrm{c}}=\left(\frac{\dot{n}_{\mathrm{co}_{2}, \ell, \mathrm{c}}^{\prime \prime}}{\dot{n}_{\mathrm{co}_{2}, \ell, \mathrm{c}}^{\prime \prime}+\dot{n}_{\mathrm{o}_{2}, \ell, \mathrm{c}}^{\prime \prime}+\dot{n}_{\mathrm{L}}^{\prime \prime}}\right) \bar{\rho}_{\mathrm{salt}}
\end{aligned}
$$

Molar density of $\mathrm{O}_{2}$ is calculated in the same way as that of $\mathrm{CO}_{2}$ :

$$
\begin{aligned}
& \bar{\rho}_{\mathrm{o}_{2}, \mathrm{~g}, \mathrm{c}}=\left(\frac{\dot{n}_{\mathrm{o}_{2}, \mathrm{~g}, \mathrm{c}}^{\prime \prime}}{\dot{n}_{\mathrm{co} 2, \mathrm{~g}, \mathrm{c}}^{\prime \prime}+4.76 \dot{n}_{\mathrm{o} 2, \mathrm{~g}, \mathrm{c}}^{\prime \prime}}\right)\left(\frac{101.325}{\bar{R} T}\right) \\
& \bar{\rho}_{\mathrm{o}_{2}, \ell, \mathrm{c}}=\left(\frac{\dot{n}_{\mathrm{o}_{2}, \ell, \mathrm{c}}^{\prime \prime}}{\dot{n}_{\mathrm{co}_{2}, \ell, \mathrm{c}}^{\prime \prime}+\dot{n}_{\mathrm{o}_{2}, \ell, \mathrm{c}}^{\prime \prime}+\dot{n}_{\mathrm{L}}^{\prime \prime}}\right) \bar{\rho}_{\mathrm{salt}}
\end{aligned}
$$

\subsubsection{Transfer Current Density Equations}

A literature search has found no model for molten carbonate cathode current density that matches all experimental data. Of those models available, the one presented by Wilemski [17] has been selected. Wilemski presents a Butler-Volmer equation:

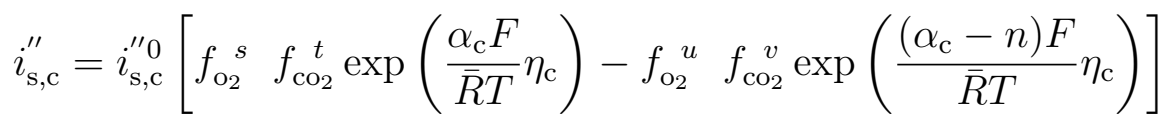

where the overpotential $\eta_{\mathrm{c}}=V_{\mathrm{c}}$. The factors $\mathrm{f}_{\mathrm{O}_{2}}$ and $\mathrm{f}_{\mathrm{co}_{2}}$ are given by,

$$
\begin{gathered}
f_{\mathrm{o}_{2}}=\left\{\begin{array}{c}
\bar{\rho}_{\mathrm{o}_{2}, \mathrm{~s}, \mathrm{c}} \\
\bar{\rho}_{\mathrm{o}_{2}, \mathrm{ref}}
\end{array}\right\} \\
f_{\mathrm{co}_{2}}=\left\{\frac{\bar{\rho}_{\mathrm{co}_{2}, \mathrm{~s}, \mathrm{c}}}{\bar{\rho}_{\mathrm{co}_{2}, \mathrm{ref}}}\right\}
\end{gathered}
$$

The values of $s, t, u$, and $v$ are given by

$$
\begin{aligned}
s & =\sigma+\alpha / 4 \\
t & =\tau+\alpha / 2 \\
u & =\sigma-(n-\alpha) / 4 \\
v & =\tau-(n-\alpha) / 2
\end{aligned}
$$

Overall electron transfer ( $\mathrm{n})$ is assumed to be 2 and according to Wilemski [17] the model is best described by values of $\sigma \approx 0.4, \tau \approx 0.0$ and $\alpha_{\mathrm{c}}=0.75 . \eta_{\mathrm{c}}$ is the overpotential loss at 
cathode. The standard exchange current density (in $\mathrm{A} / \mathrm{m}^{2}$ ) according to the model [17] is given by,

$$
i_{\mathrm{s}, \mathrm{c}}^{\prime \prime}=k_{\mathrm{c}}^{0} \exp \left[\frac{E_{\mathrm{c}}\left(T-T_{923}\right)}{T_{923} T}\right] P_{\mathrm{o}_{2}}^{\sigma} P_{\mathrm{co}_{2}}^{\tau}
$$

$E_{\mathrm{c}}$ was estimated to be $5800 \mathrm{~K}$, and $k_{\mathrm{c}}^{0}$ to be $7.8 \mathrm{~A} / \mathrm{m}^{2}$. The values of the partial pressures, $P_{\mathrm{O}_{2}}$ and $P_{\mathrm{Co}_{2}}$ are 0.33 and $0.67 \mathrm{~atm}$ respectively. The values of the molar densities (in $\mathrm{kmol} / \mathrm{m}^{3}$ ) of $\mathrm{CO}_{2}$ and $\mathrm{O}_{2}$ at the surface of the electrode are determined from the surface current density and the liquid-solid mass transfer coefficients

$$
\begin{aligned}
& \bar{\rho}_{\mathrm{co}_{2}, \mathrm{~s}, \mathrm{c}}=\bar{\rho}_{\mathrm{co}_{2}, \ell, \mathrm{c}}-\frac{i_{\mathrm{s}, \mathrm{c}}^{\prime \prime}}{2 F k_{\ell-\mathrm{s}, \mathrm{co}_{2}}} \\
& \bar{\rho}_{\mathrm{o}_{2}, \mathrm{~s}, \mathrm{c}}=\bar{\rho}_{\mathrm{o}_{2}, \ell, \mathrm{c}}-\frac{i_{\mathrm{s}, \mathrm{c}}^{\prime \prime}}{4 F k_{\ell-\mathrm{s}, \mathrm{o} 2}}
\end{aligned}
$$

Wilemski's coefficients are based on reactions in $\mathrm{Li} / \mathrm{Na} / \mathrm{K}$ eutectic.

The surface current density equation in cathode described by equation 3.24 also involves the reverse reaction part which can be considered negligible for high values of overpotential, $\eta_{\mathrm{c}}$ but which might be substantial for low values of the overpotential, $\eta_{\mathrm{c}}$. Initially, the reverse reaction was neglected due to computational difficulties and the belief that it was unimportant. This gave a simpler equation of the Tafel form. Results showed, however, that the reverse reaction could not be neglected without seriously compromising accuracy. Changes were made to make the numerical scheme stable with the reverse reaction in place, and the full Butler-Volmer equation was used.

\subsection{Downflow in Packed Bed Anode}

The equation for the $\mathrm{CO}_{2}$ production is:

$$
\mathrm{C}+2 \mathrm{CO}_{3}^{=} \rightarrow 3 \mathrm{CO}_{2}+4 e^{-}
$$

The equation for the $\mathrm{CO}$ production is:

$$
2 \mathrm{C}+\mathrm{CO}_{3}^{=} \rightarrow 3 \mathrm{CO}+2 e^{-}
$$

As in the cathode, the packed bed anode consists of an electrically-connected porous bed. The openings in the bed allow passage of molten salt with carbon particles and generated gases entrained. Unlike the cathode bed, which acted as an electrode, the anode bed acts 
only as a current collector. The carbon particles themselves act as the anode, exchanging electronic current with each other and with the bed through collisions as shown in figure 4 . Carbon entrained in the molten salt is pumped downward into the bed through the electrode

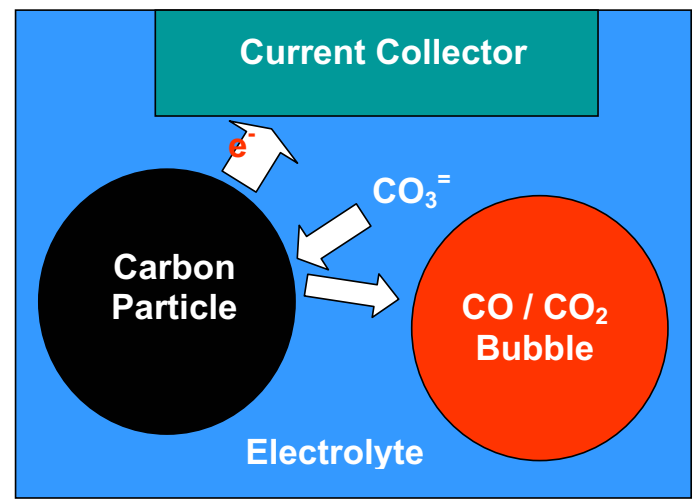

Figure 4: Carbon particle exchanging current with the bed.

plates. The carbonate ion, $\mathrm{CO}_{3}^{=}$, traveling from the cathode to anode through ionic conduction, diffuses through the molten salt electrolyte and reacts on the surface of the anode carbon to form $\mathrm{CO}$ and $\mathrm{CO}_{2}$, the ratio depending upon the chemical equilibrium and kinetics. The downward velocity of the electrolyte is such that the entrained carbon (lighter than molten salt) and the formed $\mathrm{CO} / \mathrm{CO}_{2}$ are kept flowing downwards. As explained previously, the analysis done so far neglects the production of $\mathrm{CO}$ and considers only the production of $\mathrm{CO}_{2}$. Figure 5 shows how the dependent and independent variables have been setup within the anode packed bed.

\subsubsection{Modeling Anode Packed Bed through linear ODE's}

The anode model consists of five simultaneous first-order ordinary differential equations.

$\mathrm{CO}_{2}$ in gas and liquid phase:

$$
\begin{aligned}
& \frac{d \dot{n}_{\mathrm{co}, \mathrm{g}, \mathrm{a}}^{\prime \prime}}{d x_{\mathrm{a}}}=-K_{\mathrm{Co}_{2}, \mathrm{~g}-\ell, \mathrm{a}} A_{\mathrm{B}, \mathrm{CO}_{2}, \mathrm{a}}^{\prime \prime \prime}\left(\frac{\bar{R} T}{H_{\mathrm{CO}_{2}}} \bar{\rho}_{\mathrm{CO}_{2}, \mathrm{~g}, \mathrm{a}}-\bar{\rho}_{\mathrm{CO}_{2}, \ell, \mathrm{a}}\right) \\
& \frac{d \dot{n}_{\mathrm{co}, \ell, \mathrm{a}}^{\prime \prime}}{d x_{\mathrm{a}}}=K_{\mathrm{co}_{2}, \mathrm{~g}-\ell, \mathrm{a}} A_{\mathrm{B}, \mathrm{co}_{2}, \mathrm{a}}^{\prime \prime \prime}\left(\frac{\bar{R} T}{H_{\mathrm{co}_{2}}} \bar{\rho}_{\mathrm{CO}_{2}, \mathrm{~g}, \mathrm{a}}-\bar{\rho}_{\mathrm{CO}_{2}, \ell, \mathrm{a}}\right)+\left(\frac{3}{4 F}\right) A_{\mathrm{C}, \mathrm{a}}^{\prime \prime \prime} i_{\mathrm{s}, \mathrm{a}}^{\prime \prime}
\end{aligned}
$$

$\mathrm{C}$ in solid phase:

$$
\frac{d \dot{n}_{\mathrm{C}, \mathrm{s}, \mathrm{a}}^{\prime \prime}}{d x_{\mathrm{a}}}=-\left(\frac{1}{4 F}\right) A_{\mathrm{C}, \mathrm{a}}^{\prime \prime \prime} i_{\mathrm{s}, \mathrm{a}}^{\prime \prime}
$$




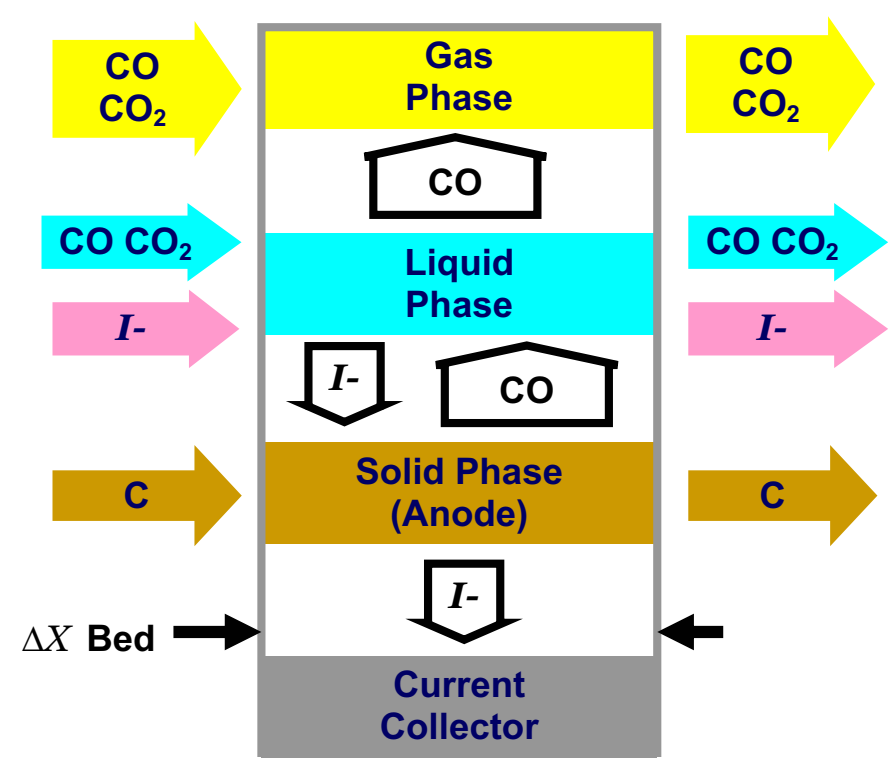

Figure 5: Anode Model showing the Dependent and Independent Variables.

where $A_{\mathrm{C}, \mathrm{a}}^{\prime \prime \prime}$ is given as in equation 3.45 and developed in Appendix A.5.

According to the ohm's law within the anode packed bed we get:

$$
\frac{d V_{\mathrm{a}}}{d x_{\mathrm{a}}}=-i_{\mathrm{a}}^{\prime \prime} R_{\mathrm{a}}
$$

where the resistivity, $R_{\mathrm{a}}$, is given as indicated in table 2 .

The anodic current density dependence on the surface current is given by:

$$
\frac{d i_{\mathrm{a}}^{\prime \prime}}{d x_{\mathrm{a}}}=-i_{\mathrm{s}, \mathrm{a}}^{\prime \prime} A_{\mathrm{C}, \mathrm{a}}^{\prime \prime \prime}
$$

\subsubsection{Initial Conditions for ODE's}

The liquid entering the anode has contains carbon particles but no $\mathrm{CO}_{2}$ bubbles. The mass transfer correlations used, however, require some gas flux in order to calculate liquid-gas mass transfer. This requirement has some basis in physics, since gas-filled nucleation sites on the carbon particles and the current collector are necessary for the $\mathrm{CO}_{2}$ to come out of solution. The initial condition for gaseous $\mathrm{CO}_{2}$ flux was selected as a seeding value:

$$
\dot{n}_{\mathrm{co}_{2}, \mathrm{~g}, \mathrm{a}}^{\prime \prime}(0)=3 \times 10^{-3}
$$


The initial conditions for dissolved gas mole flux in the liquid phase are based on the liquid salt superficial velocity and the assumption that the salt is saturated with gases at the appropriate partial pressures.

$$
\dot{n}_{\mathrm{co}_{2}, \ell, \mathrm{a}}^{\prime \prime}(0)=P_{\mathrm{atm}} H_{\mathrm{co}_{2}} U_{\mathrm{OL}, \mathrm{a}}
$$

The initial condition for the mole flux of carbon depends upon current flux and the overfeed factor. If $\gamma_{\mathrm{C}}$ is the amount of carbon overfeed, then the initial mole flux of carbon is given by,

$$
\dot{n}_{\mathrm{C}, \mathrm{s}, \mathrm{a}}^{\prime \prime}(0)=\gamma_{\mathrm{C}} \cdot \frac{i_{0}^{\prime \prime}}{4 F}
$$

The initial condition for voltage is based on an assumed division of available driving voltage between the anode and the cathode:

$$
V_{\mathrm{a}}(0)=\beta \cdot\left(V_{\mathrm{oc}}-V_{\text {cell }}\right)
$$

The initial condition for ionic current flux is the cell current density based on face area:

$$
i_{\mathrm{a}}^{\prime \prime}(0)=i_{0}^{\prime \prime}
$$

\subsubsection{Mass Transfer Equations in Anode Packed Bed}

Various correlations describing mass transfer analysis in the packed bed anode are referred from the literature and tabulated in table 2 . Once the combined liquid-solid holdup $\left(h_{\mathrm{LS}}\right)$ and the liquid holdup $\left(h_{\mathrm{L}}\right)$ are known, the liquid, solid, and gas holdups can computed using:

$$
\begin{aligned}
& h_{\mathrm{S}}=h_{\mathrm{LS}}-h_{\mathrm{L}} \\
& h_{\mathrm{G}}=1-h_{\mathrm{LS}}
\end{aligned}
$$

The superficial velocities used in the above correlations are all in $\mathrm{m} / \mathrm{sec}$. The liquid superficial velocity $U_{\text {oL }}$ can be set to any feasible value within the range specified by the correlation. $U_{\mathrm{OG}}$ is determined from the mole flux and the ideal gas law:

$$
U_{\mathrm{OG}}=\dot{n}_{\mathrm{co}_{2}, \mathrm{~g}, \mathrm{a}}^{\prime \prime} \frac{\bar{R} T}{101.325}
$$

where the molar flux of $\mathrm{CO}_{2}\left(\dot{n}_{\mathrm{co}_{2}, \mathrm{~g}, \mathrm{a}}^{\prime \prime}\right)$ in the gas phase is determined from the solution of the differential equations. 
Using correlations in table 2 to determine gas-side and liquid-side coefficients, the overall gas-liquid mass transfer coefficient is,

$$
K_{\mathrm{GL}} A_{\mathrm{B}}^{\prime \prime \prime} \quad(/ \mathrm{sec})=\frac{1}{\left(1 / k_{\mathrm{L}} A_{\mathrm{B}}^{\prime \prime \prime}+1 / k_{\mathrm{G}} A_{\mathrm{B}}^{\prime \prime \prime}\right)}
$$

The gas-liquid mass transfer coefficient $\left(K_{\mathrm{co} 2, \mathrm{~L}, \mathrm{a}} A_{\mathrm{B}}^{\prime \prime \prime}\right)$ for $\mathrm{CO}_{2}$ can then be found easily from the gas properties of $\mathrm{CO}_{2}$.

The liquid-solid side mass transfer coefficient in the anode is given by

$$
K_{\mathrm{s}, \mathrm{i}}=\frac{S h D_{\mathrm{i}}}{d_{\mathrm{C}}\left(x_{\mathrm{a}}\right)}
$$

where $d_{\mathrm{C}}\left(x_{\mathrm{a}}\right)$ is the instantaneous diameter of the carbon particles (given by equation 3.46 ) that varies with the anode bed length $\left(x_{\mathrm{a}}\right), S h$ is Sherwood number given from the correlation in table 2 , and $D$ is the molecular diffusivity of $\mathrm{CO}_{2}$ in the molten salt.

The surface area of carbon per unit volume of the bed is given by equation 3.45 which was developed in appendix A.5.

$$
A_{\mathrm{C}, \mathrm{a}}^{\prime \prime \prime}=\frac{6 h_{\mathrm{S}}}{d_{\mathrm{C}}\left(x_{\mathrm{a}}\right)}\left(1-\zeta_{\mathrm{a}}\right)
$$

where $d_{\mathrm{C}}\left(x_{\mathrm{a}}\right)$ is given by,

$$
d_{\mathrm{C}}\left(x_{\mathrm{a}}\right)=d_{\mathrm{C}}(0)\left[\frac{\dot{n}_{\mathrm{C}, \mathrm{S}, \mathrm{a}}^{\prime \prime}\left(x_{\mathrm{a}}\right)}{\dot{n}_{\mathrm{C}, \mathrm{S}, \mathrm{a}}^{\prime \prime}(0)}\right]^{1 / 3}
$$

\subsubsection{Molar Density Equations}

Molar densities of $\mathrm{CO}_{2}$ in the gas phase are from the ideal gas law. Densities in the liquid phase are from mole fraction and liquid salt density. Units are $\mathrm{kmol} / \mathrm{m}^{3}$ :

$$
\begin{gathered}
\bar{\rho}_{\mathrm{co}_{2}, \mathrm{~g}, \mathrm{a}}=\frac{101.325}{\bar{R} T} \\
\bar{\rho}_{\mathrm{co}_{2}, \ell, \mathrm{a}}=\left(\frac{\dot{n}_{\mathrm{co}_{2}, \ell, \mathrm{a}}^{\prime \prime}}{\dot{n}_{\mathrm{co}_{2}, \ell, \mathrm{a}}+\dot{n}_{\ell}^{\prime \prime}}\right) \bar{\rho}_{\mathrm{salt}}
\end{gathered}
$$

where $\bar{\rho}_{\text {salt }}$ is given by $\bar{\rho}_{\text {salt }}=\rho_{\mathrm{L}} / M_{\mathrm{L}}, \rho_{\mathrm{L}}$ and $M_{\mathrm{L}}$ are respectively the density and molecular weight of the molten salt. 
Table 2: Various Correlations Used for the Anode Packed Bed

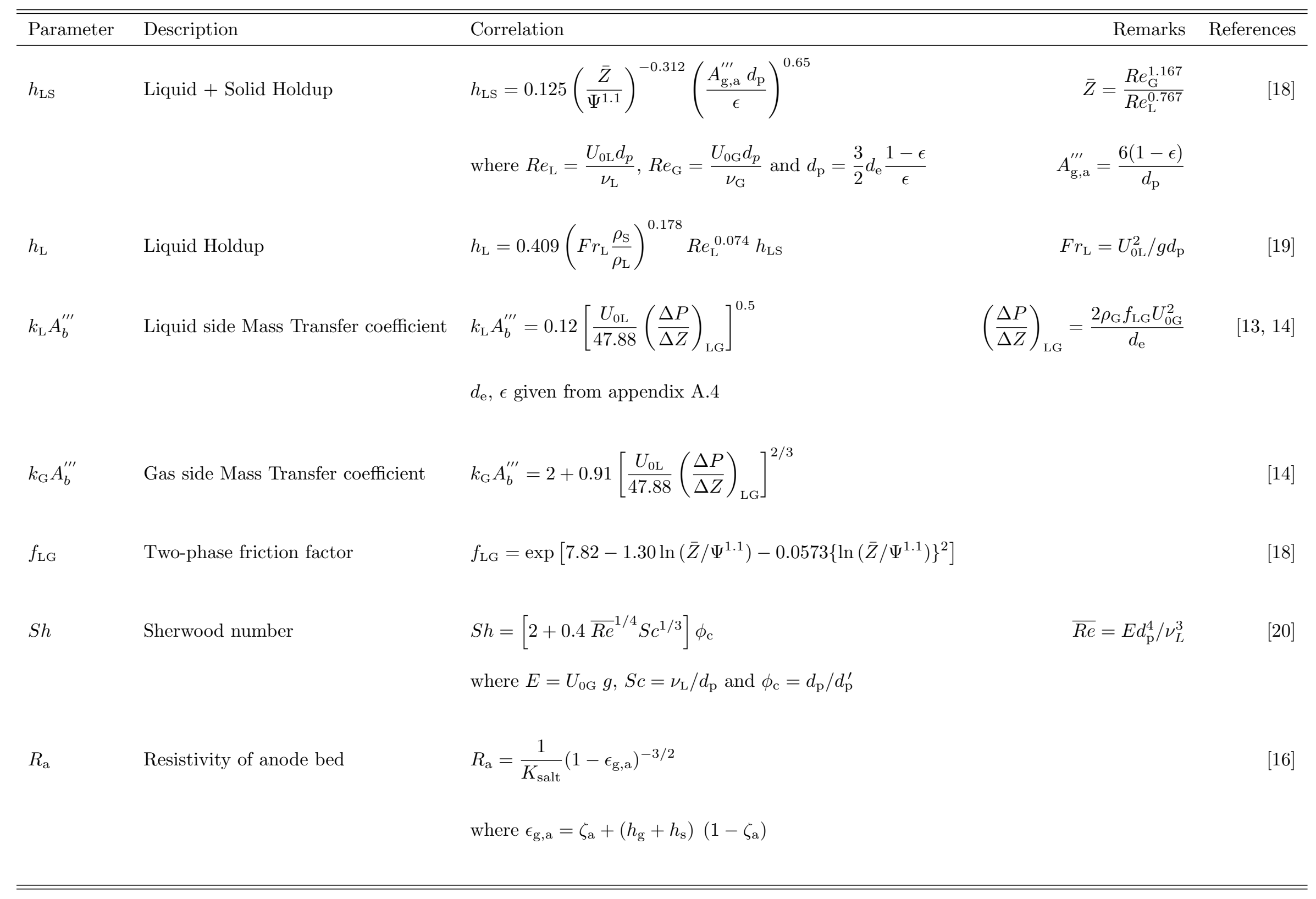




\subsubsection{Transfer Current Density Equations}

The current density equation for the anode packed bed at the carbon particle surface surface (a variation of the Butler-Volmer equation, equivalent to a Tafel equation) is given by

$$
i_{\mathrm{s}, \mathrm{a}}^{\prime \prime}=i_{\mathrm{s}, \mathrm{a}, 0}^{\prime \prime}\left(\frac{\bar{\rho}_{\mathrm{Co}_{2}, \mathrm{~s}, \mathrm{a}}}{\bar{\rho}_{\mathrm{CO}_{2}, \mathrm{ref}}}\right)^{-3} \exp \left[\frac{\alpha_{\mathrm{a}} n F}{\bar{R} T} \eta_{\mathrm{a}}\right]
$$

where $\alpha_{\mathrm{a}} n=1.55, \eta_{\mathrm{a}}$ is the overpotential loss at anode and is given by $\eta_{\mathrm{a}}=V_{\mathrm{a}}-\Delta V_{\mathrm{CR}}$, and $i_{\mathrm{s}, \mathrm{a}, 0}^{\prime \prime}$ is given by,

$$
i_{\mathrm{s}, \mathrm{a}, 0}^{\prime \prime}=5.8 \times 10^{9} \exp \left(\frac{-22175}{T}\right)
$$

These transfer current density equations have been developed after doing a regression analysis on the data in appendix $\mathrm{B}$ of [21]. The molar density of $\mathrm{CO}_{2}$ at reference conditions inside the molten salt depends upon the Henry's law at the reference conditions. The molar density of $\mathrm{CO}_{2}$ at the surface of carbon particle (where the reaction takes place), $\bar{\rho}_{\mathrm{Co}_{2}, \mathrm{~s}, \mathrm{a}}$ is given by

$$
\bar{\rho}_{\mathrm{CO}_{2}, \mathrm{~s}, \mathrm{a}}=\bar{\rho}_{\mathrm{CO}_{2}, \ell, \mathrm{a}}+\frac{3}{4 F} \frac{i_{\mathrm{s}, \mathrm{a}}^{\prime \prime}}{k_{\ell-\mathrm{s}, \mathrm{co}_{2}}}
$$

Voltage drop due to contact resistance of the carbon particles is given by

$$
\Delta V_{\mathrm{CR}}=\frac{i_{\mathrm{s}, \mathrm{a}}^{\prime \prime} A_{\mathrm{C}, \mathrm{a}}^{\prime \prime \prime}}{\left(A_{\mathrm{g}, \mathrm{a}}^{\prime \prime \prime} h_{\mathrm{s}}\right)^{2 / 3}}
$$

where $A_{\mathrm{g}, \mathrm{a}}^{\prime \prime \prime}$ is from table 2 . 


\section{Experimental}

This section does not include any experimental work because none was done; the project consisted only of computer. Computer solution technique has been discussed in this section.

After the model equations and correlations had been established, they were programmed into the Matlab ${ }^{T M}$ numerical analysis package and solved for a range of input parameters. This section discusses the techniques that were used to solve different individual models and how the final integrated solution was achieved.

\subsection{Input Parameters}

In this section we will cover first the base case parameters, which have been tabulated in table 3.

Some of these parameters require explanation beyond that given in the table:

Table 3: Input Parameters for the Base Case

\begin{tabular}{lllc}
\hline \hline Parameter & Description & Units & Value \\
\hline$T_{\text {cell }}$ & Cell Temperature & $\mathrm{K}$ & 1000 \\
$i_{0}^{\prime \prime}$ & Current Density Feed & $\mathrm{Amp} / \mathrm{m}^{2}$ & 149.2 \\
$V_{\text {cell }}$ & Desired Cell Voltage & Volt & 0.7 \\
$\beta$ & Voltage Distribution Factor & - & 0.59922 \\
$\gamma_{\mathrm{C}}$ & Carbon Overfeed Factor & - & 3 \\
$U_{\mathrm{L}, c}$ & Superficial Velocity in Cathode Packed Bed & $\mathrm{m} / \mathrm{sec}$ & 1.8 \\
$U_{\mathrm{L}, a}$ & Superficial Velocity in Anode Packed Bed & $\mathrm{m} / \mathrm{sec}$ & 0.05 \\
$d_{\mathrm{C}}$ & Initial Diameter of Carbon Particles $\left(\right.$ at $\left.x_{\text {bed }}=0\right)$ & $\mathrm{m}$ & $74 \cdot 10^{-6}$ \\
\hline
\end{tabular}

- The current density feed is the ionic current per unit area at the interface between the anode and the cathode. The possible range of values is limited, since excessive current will result either in current remaining when the end of the bed is reached or in current remaining when chemical overpotential goes to zero as ohmic losses build.

- Carbon overfeed is the extra amount of carbon (over the normal requirement as per Faraday's law) that is fed into the anode. 
- The choice of superficial velocities in both the anode and cathode packed bed is limited by the need to maintain bubbly flow, the need to limit pressure drop, and the limitations of the holdup and mass transfer correlations used.

- The equivalent diameter of the cathode and anode packing has been chosen for either the perforated sheet plates or the electroformed nickel wire mesh, for which analysis has been conducted and appended in Appendix A.

- The carbon particle size has been chosen as per ASTM standard 200 mesh size for pulverized coal as cited on page 9-4 of [22].

\subsection{Anode and Cathode Models}

The anode and cathode models have been individually developed (figure 6 and figure 7) and then combined together while conducting cell analysis. The initial conditions for both

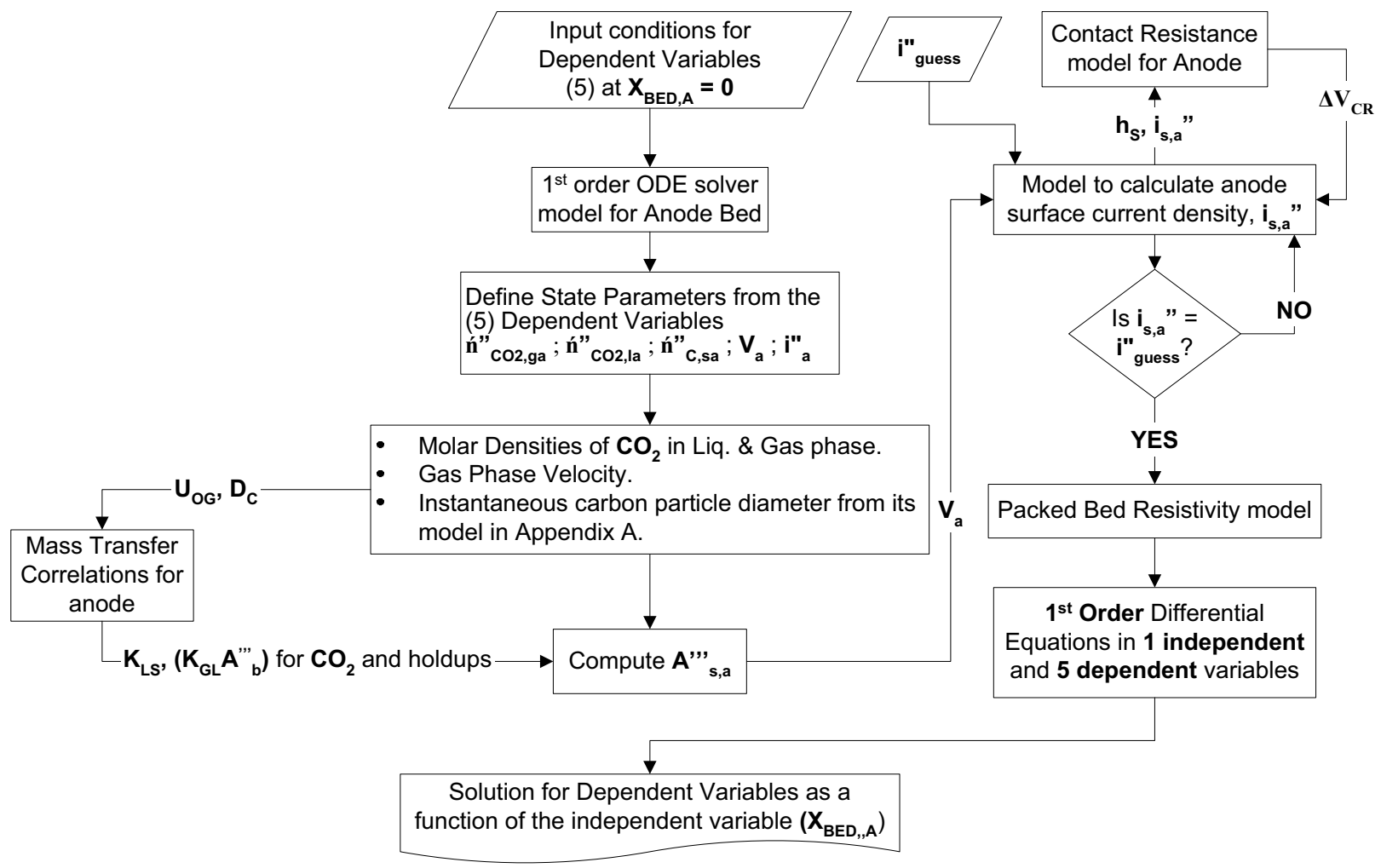

Figure 6: Flow Chart for the ANODE model.

the models has been selected as discussed in sections 3.1.2 and 3.2.2. Standard ordinary differential equation solver (ode45) is chosen in MATLAB for solving the set of differential 


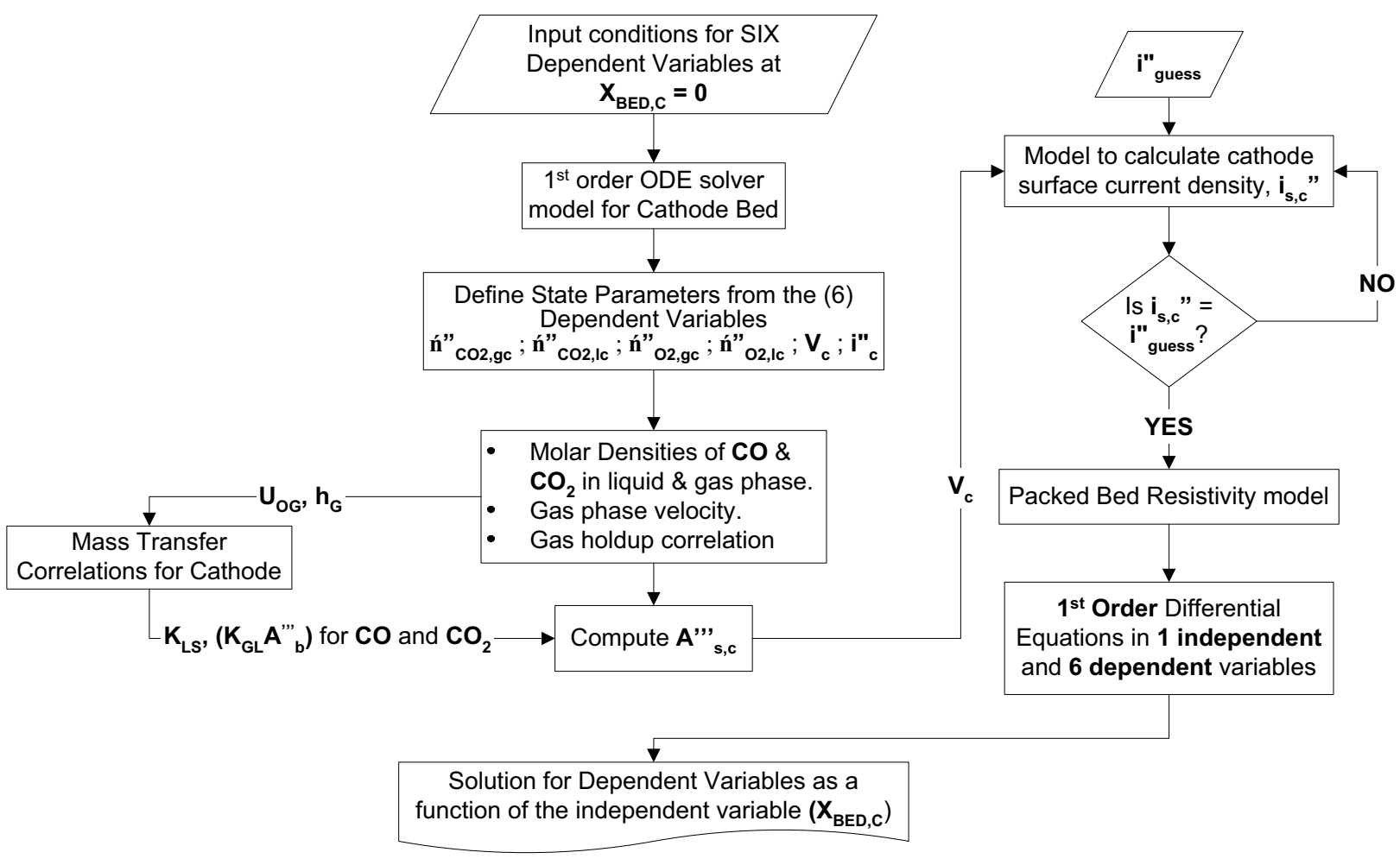

Figure 7: Flow Chart for the CATHODE model.

equations that were discussed in sections 3.1.1 and 3.2.1.

The basic idea of both models is the same. Initial conditions are passed onto the cathode and anode models. The initial values of the dependent variables enables the computation of parameters of different correlations taken from the literature. The mass transfer coefficients and holdups for different phases are determined from these correlations. These coefficients and many other parameters help in solving for the dependent variables as a function of the independent variable (bed length $x$ ).

The required cell voltage $\left(V_{\text {cell }}\right)$ is then passed onto the main program that combines the two cathode and anode models. The maximum current density that can be fed into the cell is iterated until we get a situation where the feed current gets used up in both the bed and also that the cell losses correspond to $\left(V_{\text {oc }}-V_{\text {cell }}\right)$. The corresponding bed length is found from such an analysis for both cathode and anode. The distribution factor $(\beta)$ determines the portion of cell losses contributed by anode and cathode. 


\section{Results and Discussion}

The model equations of anode and cathode were solved together by utilizing a voltage distribution function $(\beta)$ and certain base case parameters. This section shows results depicting current variations with bed length, effect of coal loading on the contact resistance, and the variation of output voltage and power density with current density.

\subsection{Base Case Results}

In this section, the results from the perforated sheet plate type packing have been reported. Figure 8 shows the distribution of overpotential losses within the anode and cathode packed bed for a typical operating point. In the cathode the losses are combination of ohmic and mass/charge transfer losses (signified by the symbol $\eta$ ) whereas in the anode the losses are a combination of ohmic losses, mass/charge transfer losses, and losses due to contact resistance for electron transfer from the current collector to the carbon particles. The ohmic voltage

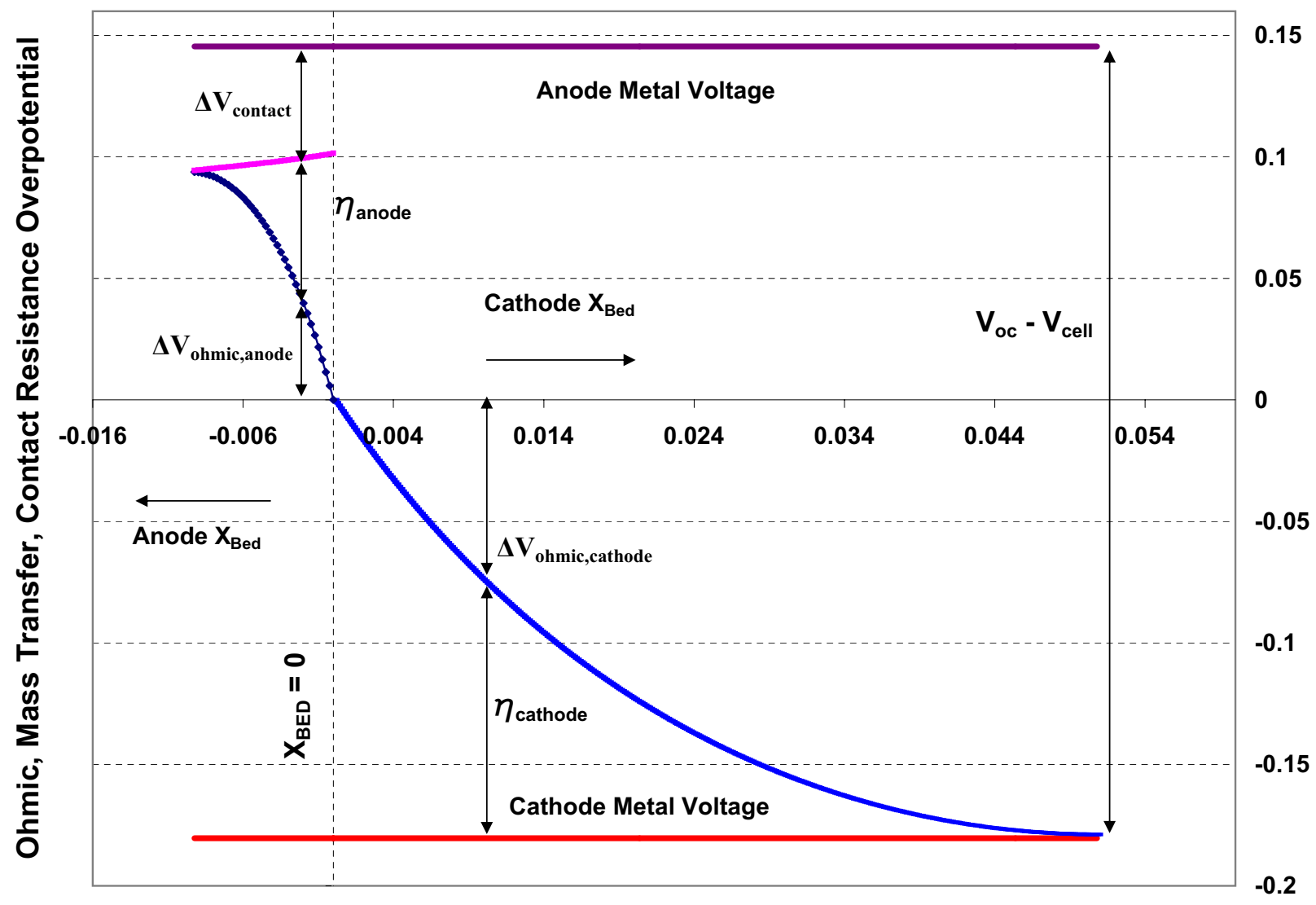

Figure 8: Overpotential losses in Cathode and Anode.

drop in the cathode packed bed is increased by the presence of gas bubbles and the electrode 
packing material (which also works as both the cathode and current collector). The ohmic voltage drop in the anode packed bed is increased by the presence of gas bubbles, the carbon particles entrained in the salt (acting as anode), and the electrode packing material (acting as current collector). The correlation for finding the resistance due to the above factors comes from the Bruggeman equation formulation indicated in Tables 1 and 2. At the start

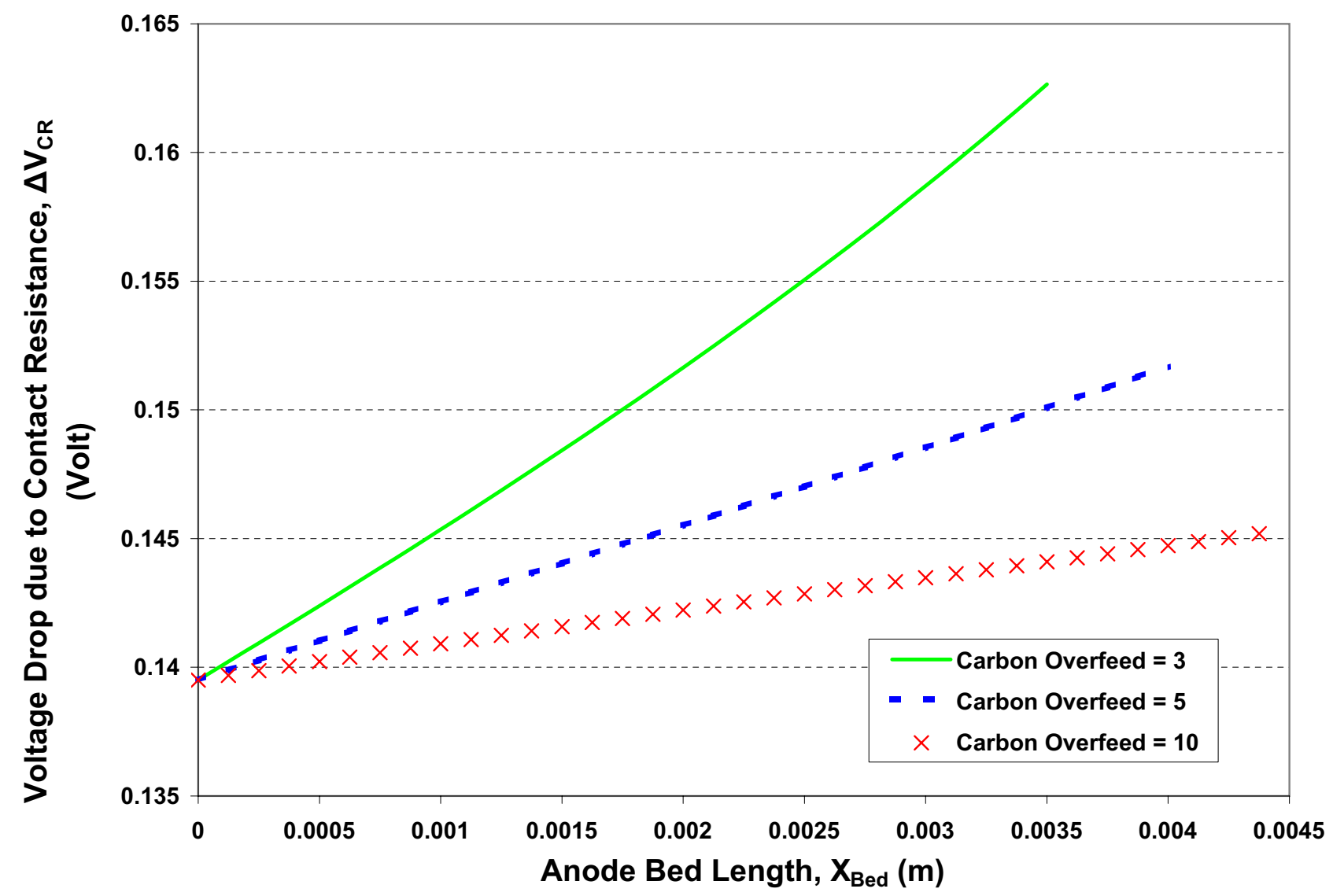

Figure 9: Effect of Carbon Overfeed on the Voltage Drop due to Contact Resistance Losses in Anode.

of the beds, the mass/charge transfer losses are substantial and ohmic losses zero, but with the increasing bed length the ohmic losses increase as distance from the anode increases, whereas the mass/charge transfer losses go down as current density decreases.

In the anode packed bed, the low collision rate of carbon particles gives rise to contact resistance losses which are quite substantial (almost 35\% of the total losses within the anode bed). The change in contact resistance losses is governed by two counteracting effects. The decreasing current density decreases contact resistance losses, while decreasing carbon flux as fuel is utilized increases contact resistance losses. For the case shown the decrease in carbon flux is dominant, and contact resistance losses increase with depth. The effect of carbon flux 
on contact resistance losses is corroborated by figure 9, which shows how increased carbon overfeed reduces contact resistance.

The figure 10 shows the power density and cell voltage on the same graph against the current density. From the plot it can be seen that for maximum cell output $\left(>200 \mathrm{~W} / \mathrm{m}^{2}\right)$ current densities in the range of $400-600 \mathrm{~A} / \mathrm{m}^{2}$ are reasonable.

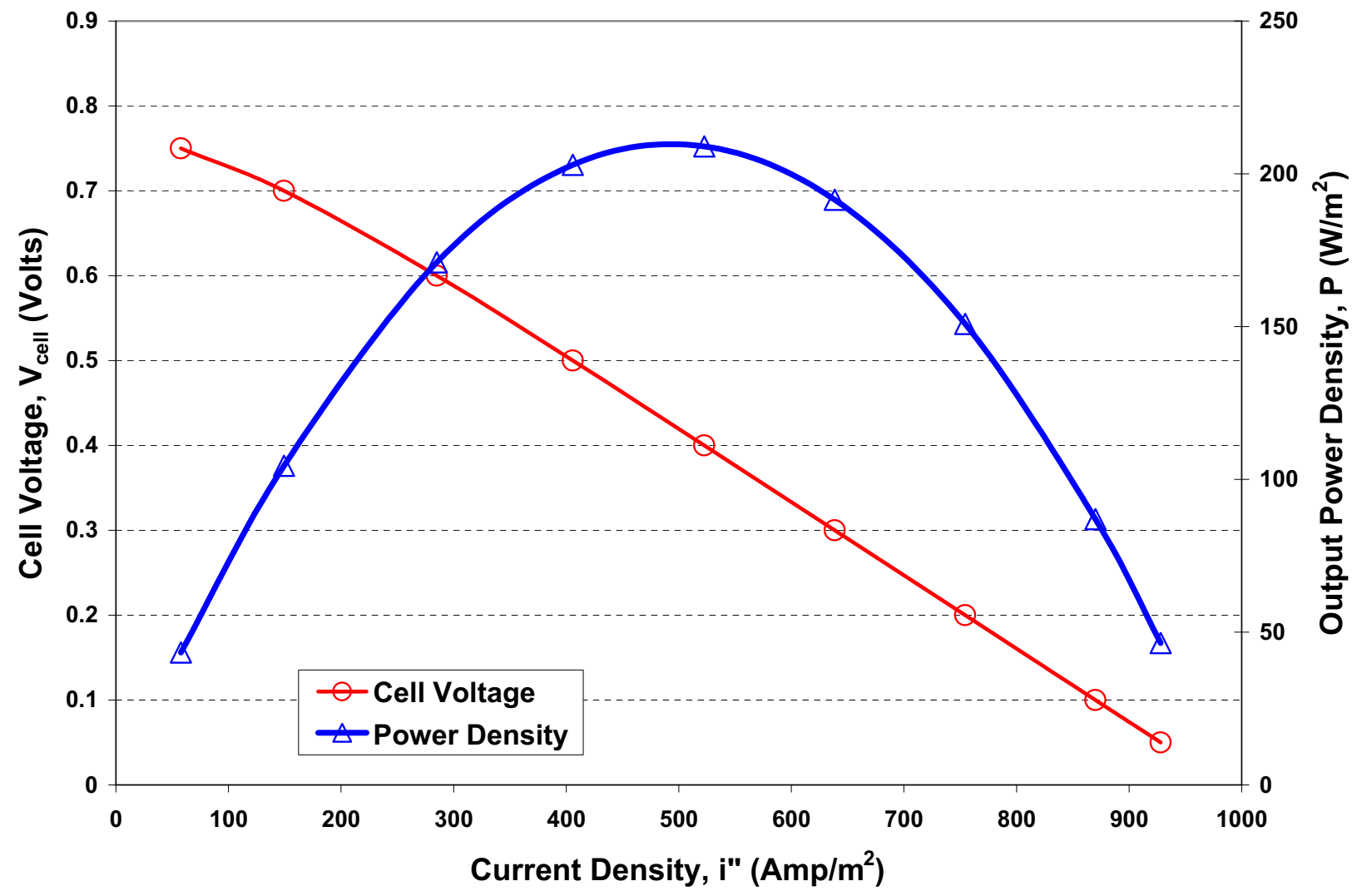

Figure 10: Power Density and Cell Voltage as against the Current Density.

For a direct carbon fuel cell, the ideal first law efficiency is

$$
\eta_{I}=\frac{\Delta G}{\Delta H^{\circ}{ }_{298}}
$$

which is $\sim 1$ for typical operating conditions. The first law efficiency of the operating cell is thus given by

$$
\eta_{v o l}=\frac{V_{\text {cell }}}{V_{\mathrm{oc}}}
$$

Since the open circuit potential of the cell studied here is approximately 1, therefore, the 
cell voltage vs current density plot as shown above in figure 10 approximately portrays net efficiency vs current density. It can also be said that the first law and second law efficiency of the cell described here are approximately the same.

The current densities that give high power densities are thus seen to give efficiencies of only $30-50 \%$. Efficiencies of $60-70 \%$ limit current densities to $150-250 \mathrm{~A} / \mathrm{m}^{2}$ and power densities to $200 \mathrm{~W} / \mathrm{m}^{2}$.

The current per electrode area variation with the bed length is shown for both anode and cathode in figure 11. The current density decreases very quickly in the anode bed because

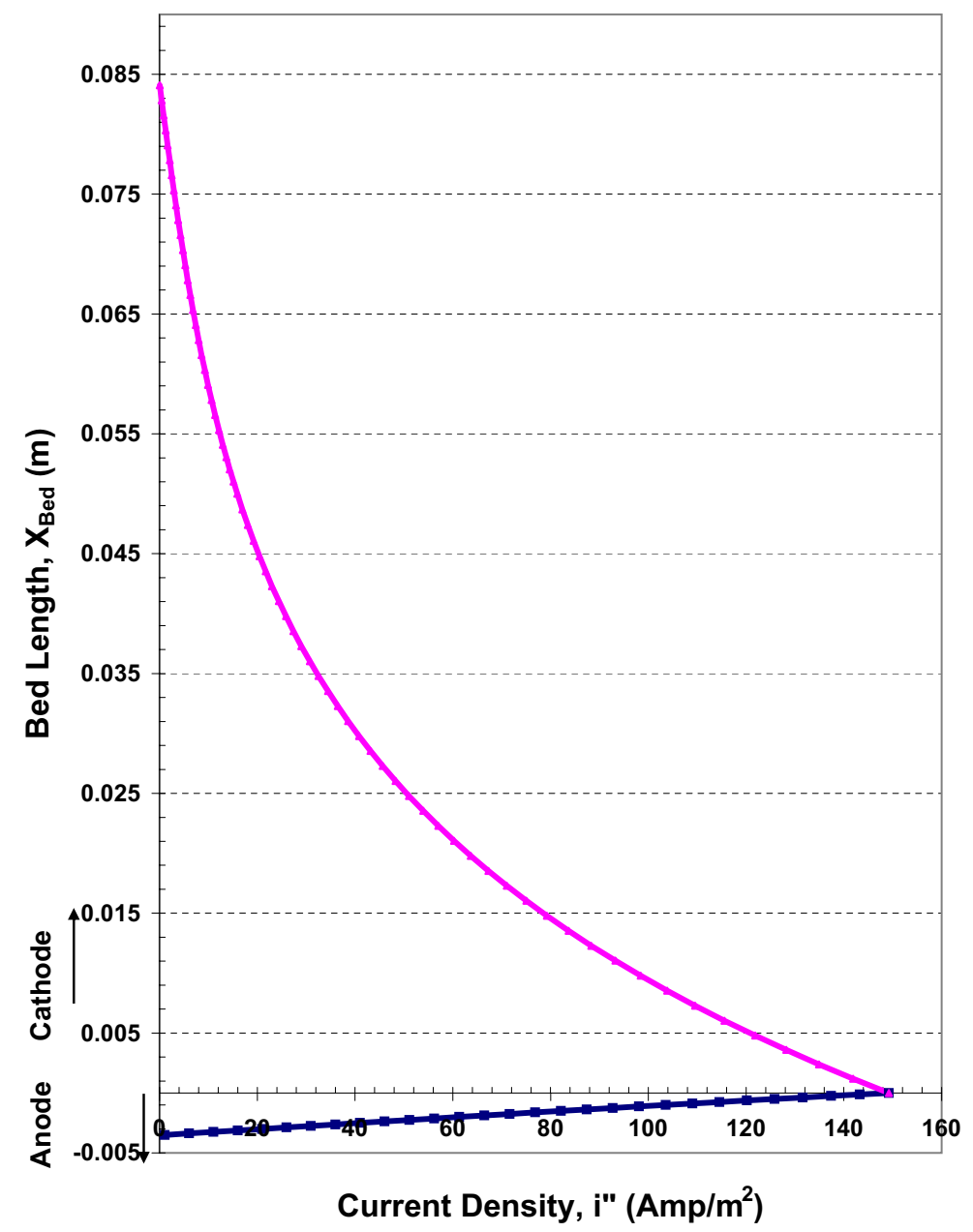

Figure 11: Variation in Current Density along the Bed Length in Anode and Cathode.

of the additional voltage drop due to the contact resistance of the carbon particles. 


\subsection{Parametric studies}

After the base case fuel cell analysis is done, it is important to understand the effects of different parameters on the fuel cell performance. The polarization curves and the power density vs current density curves are plotted for different values for cell temperature and the carbon loading and shown in figures from 12 to 15.

\subsubsection{Effect of cell temperature}

As seen from Figures 12 and 13, increase in cell temperature increases fuel cell performance quite considerably. Now as discussed in [10], the mole fraction $\mathrm{CO}_{2}$ from the anode is largely dependent upon the cell temperature. The Boudouard equilibrium predicts low $\mathrm{CO}_{2}$ yield at high cell temperatures, whereas according to [21], $\mathrm{CO}_{2}$ yield is not as low as predicted by the equilibrium. In any case, it is absolutely clear that the fuel cell performance model described in this report can be effectively optimized provided a model that can accurately predict the $\mathrm{CO}-\mathrm{CO}_{2}$ equilibrium is established.

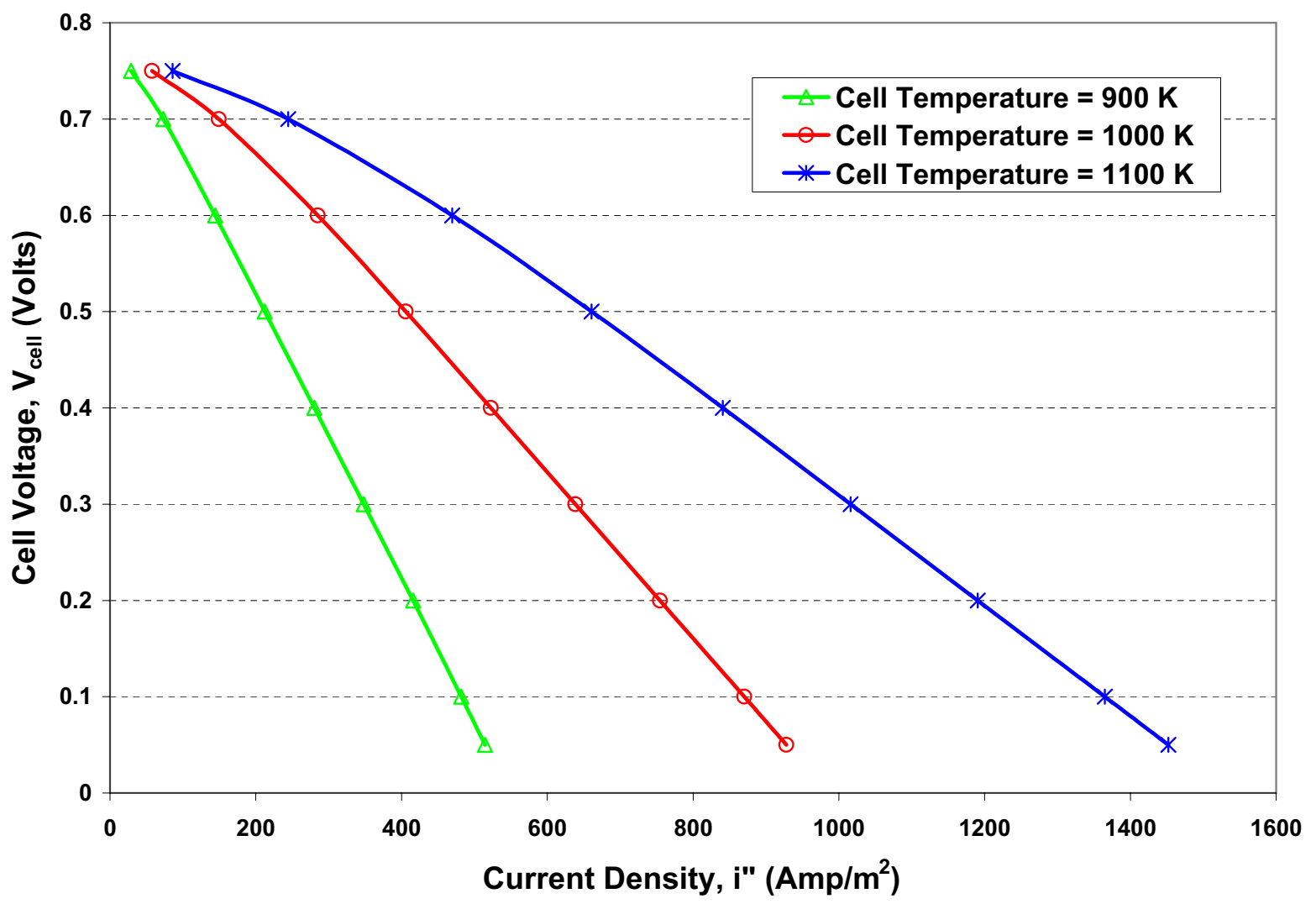

Figure 12: Effect of cell temperature on the current density - voltage relationship. 


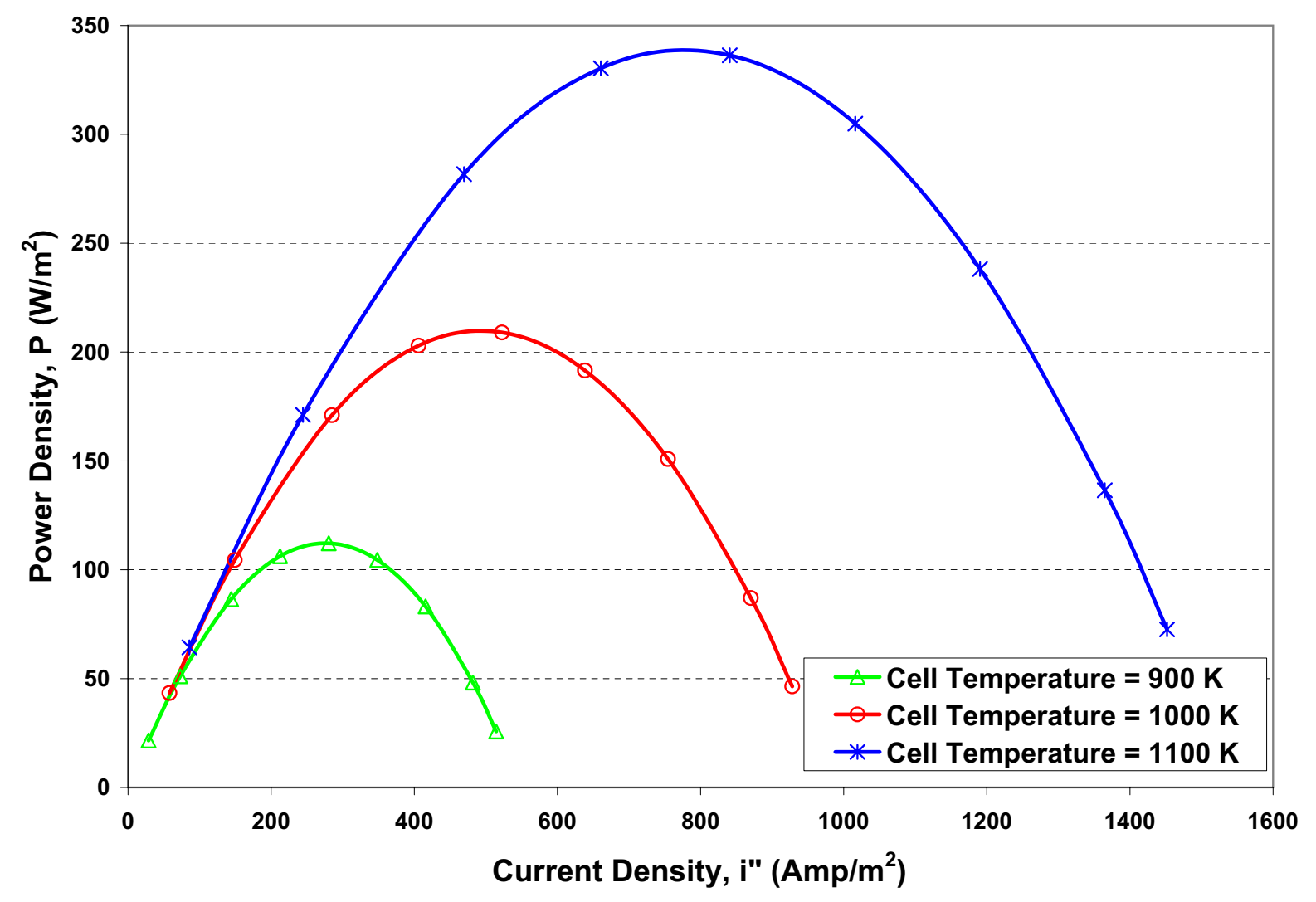

Figure 13: Effect of cell temperature on the current density - power density relationship. 


\subsubsection{Effect of carbon loading}

As seen from figures 14 and 15, increase in the carbon overfeed slightly improves the modeled performance of the fuel cell. After a relatively small increase, however, the performance is maximized and doesnt improve further. This is probably because increased ionic resistance losses due to carbon fraction in the electrolyte counteract decreased contact resistance losses.

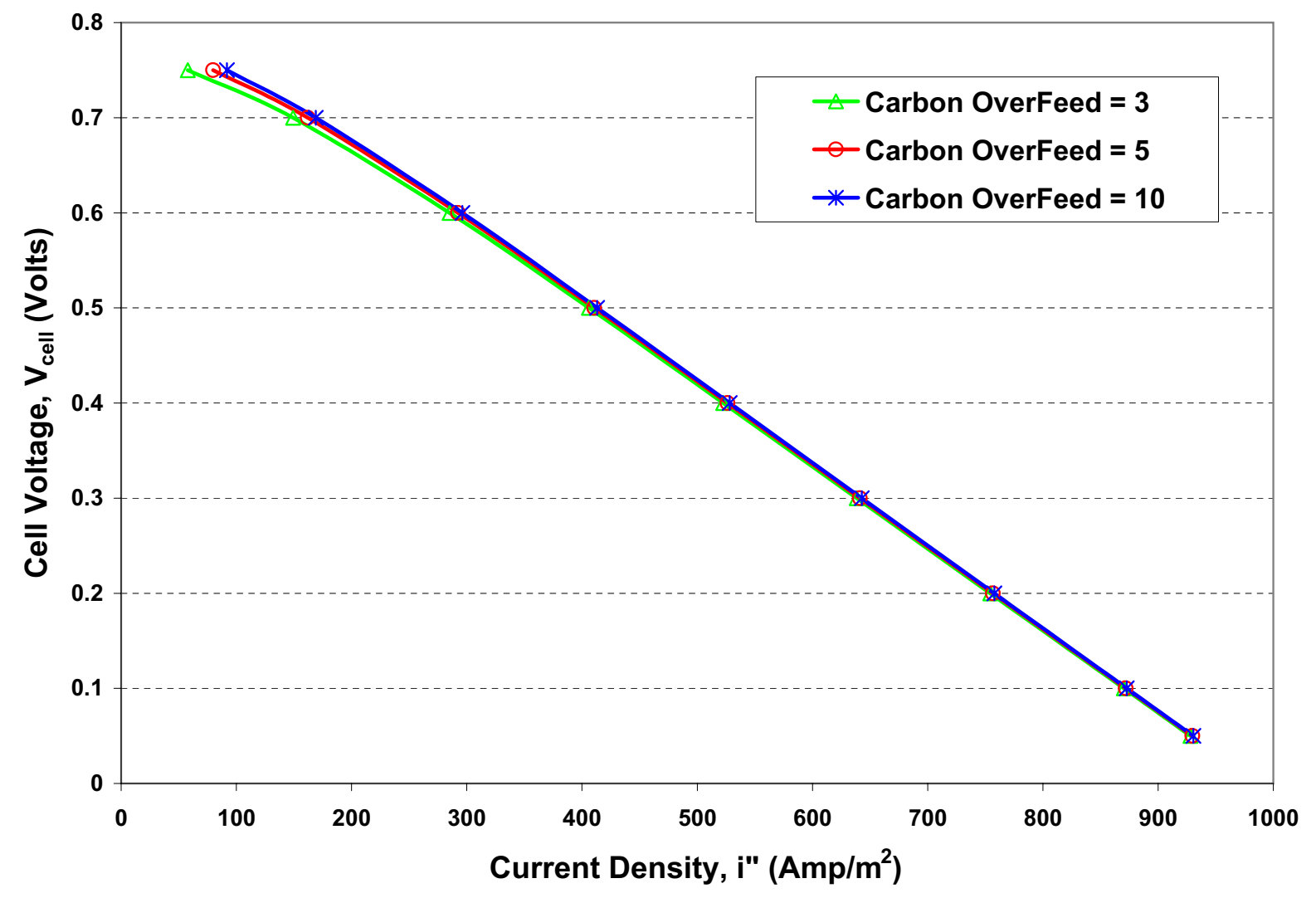

Figure 14: Effect of carbon loading on the current density - voltage relationship. 


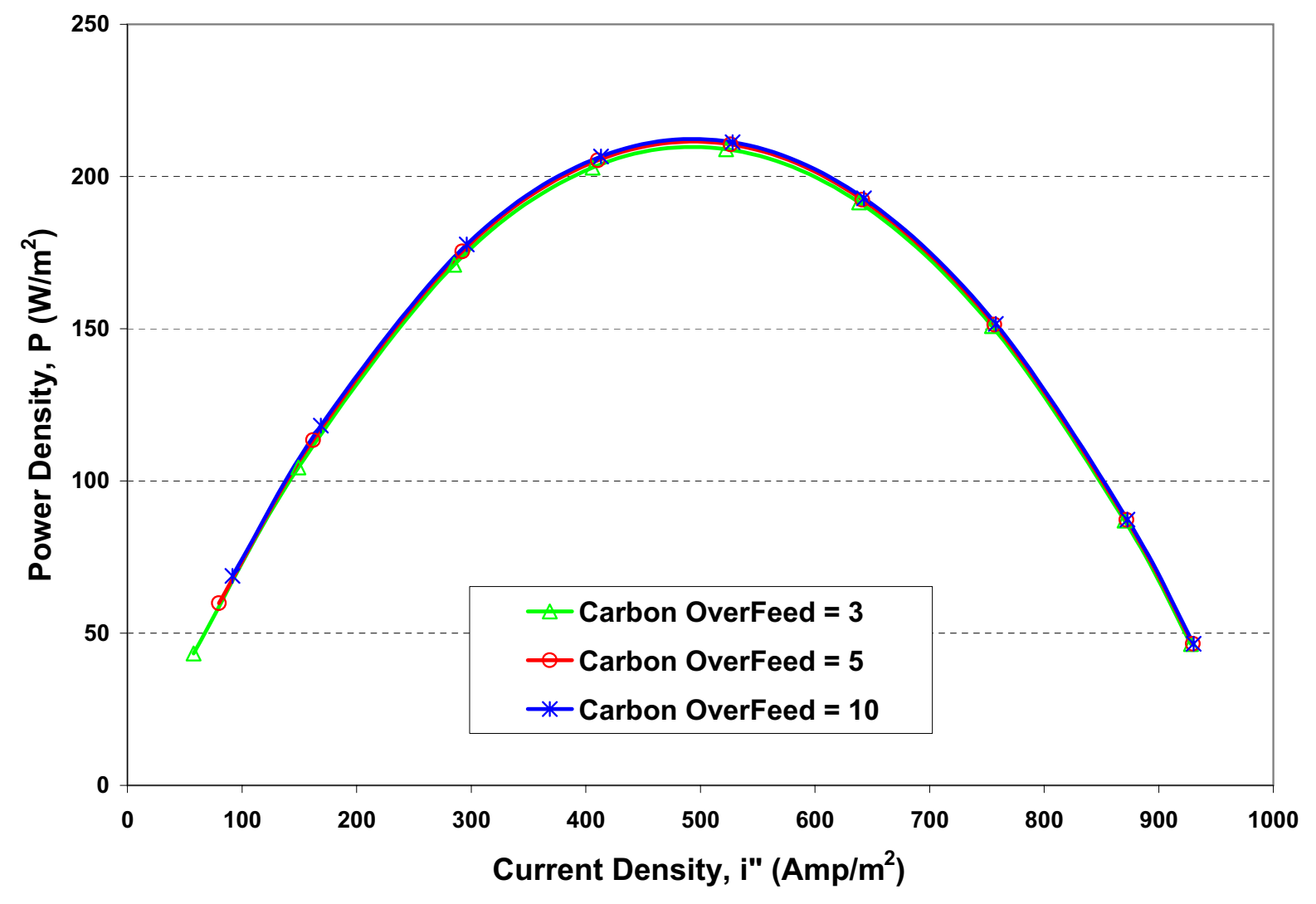

Figure 15: Effect of carbon loading on the current density - power density relationship. 


\section{Conclusions}

An appropriate design of the packed bed anode and cathode has been conceptualized for the Entrained Fuel and Oxidizer (EFO) fuel cell. The cathode involves perforated stainless steel electrode plates working both as an electrode and current collector. In the anode, carbon particles themselves act as anode and the perforated stainless steel electrode plates act as the current collector.

A preliminary energy balance of the fuel cell and the balance-of-plant was done during the initial phase of the project. During the later phase, a one-dimensional model for the fuel cell has been developed. Using an optimization routine this model is able to establish cell voltage vs current density relationships or the polarization curve given certain load conditions. The model is also able to find out appropriate bed length for each iterated case. One aspect that could not be covered during the course of the project was to develop a comprehensive optimization routine that could project the optimum bed length for both cathode and anode given certain fuel cell load conditions.

The results from the energy balance reveals that the efficiency is determined predominantly by $\mathrm{CO} / \mathrm{CO}_{2}$ ratio leaving the anode. Experiments by others have shown that $\mathrm{CO}_{2}$ concentrations exceed those predicted by Boudouard equilibrium. Therefore, a useful alternate model is clearly necessary for good cell design and accurate prediction of cell performance.

The effect of temperature is investigated both during the energy balance of the cell and the balance-of-plant and also while analyzing the one-dimensional fuel cell model. If decoupled from the $\mathrm{CO} / \mathrm{CO}_{2}$ ratio, temperature has a relatively small effect on first law efficiency. Increasing cell temperature generally increases work output slightly and also increases the value of the waste heat. However, the most important effects of temperature is on the reaction rates. This is witnessed from the increase in cell performance with the increase in cell temperature. However, high temperature also leads to low $\mathrm{CO}_{2}$ yield which in turn tends to reduce the first law efficiency. Therefore, an optimum cell temperature will lead to optimum cell performance along with the first law efficiency. This is only possible if an alternate model to describe the $\mathrm{CO} / \mathrm{CO}_{2}$ ratio leaving the anode is built. It may be, for cells of the type described here, that there is considerable temperature difference between the anode and the cathode. Determining this difference will require information on the thermodynamic properties of $\mathrm{CO}_{3}^{=}$in molten salts. Therefore, the energy balance analysis was done assuming 
isothermal cell.

One of the major achievements of this project is to understand that the packed bed geometry is capable of producing large area per unit volume available for reaction. Large surface area when used for the chemical reaction produces high mass transfer rates and good economies of scale. Moreover, the mass transfer processes in the direct carbon molten carbonate (DCMC) fuel cell are surely effective but still need more investigation before reaching an optimum design. 


\section{Future Work}

The following issues have to be addressed for a future fuel cell performance model.

- Further work is needed to study the factors affecting the $\mathrm{CO} / \mathrm{CO}_{2}$ balance in direct carbon molten carbonate fuel cells. The Boudouard equilibrium has been shown by the SRI workers [21] to be inconsistent in predicting the correct equilibrium. The determination of an accurate model will be helpful in optimizing the fuel cell performance.

- Development of more data on thermodynamic and transport properties in molten carbonate melts is needed to investigate the anode and cathode at different temperatures. The assumption of isothermal cell while conducting energy balance is true in ideal case scenario but in reality there will be some difference between the temperature of cathode and anode. The determination of these properties will provide accurate prediction of the performance of the fuel cell and the whole plant.

- Construction of a laboratory-scale version of the porous bed electrode cell will help in comparing the model results with the experimental results.

- Development of accurate transfer current density equations for cathode and anode are needed as against the currently used Wilemski model [17] for cathode and Ateya model [21] for anode. A model describing the exchange current density accurately for both anode and cathode is also needed.

- Axial diffusivity should also be included in the future model to predict accurate fuel cell performance.

The analysis and development of this design has led to several innovative ideas that

should increase the efficiency and the power density of the cell. These ideas, however, are intellectual properties that have not yet been disclosed to the Patent Office. They will therefore not be discussed here. 


\section{Appendices}

\section{A Analysis of the Packed Bed Parameters}

\section{A.1 Calculation of Area per Unit Volume of the Packed Bed}

Here we will consider a packed bed of rectangular cross-section with packing sheet plates stacked in a staggered configuration to enhance mass transfer. We get for the surface area of one such packing sheet as,

$$
S_{\text {plate }}=N_{\text {hole }} \pi D_{\mathrm{h}} t+2 L_{\mathrm{b}} W_{\mathrm{b}}(1-O A)
$$

where $N_{\text {hole }}$ is the number of holes in one packing sheet, $D_{\mathrm{h}}$ is the diameter of the hole, $t$ the thickness of the packing sheet, $L_{\mathrm{b}}$ and $W_{\mathrm{b}}$ are the length and breadth of the packing sheet, $O A$ is the open area of one packing sheet.

The number of holes in one packing sheet, $N_{\text {hole }}$ can be found out from,

$$
N_{\text {hole }}=\frac{L_{\mathrm{b}} W_{\mathrm{b}}(O A)}{\left(\pi D_{\mathrm{h}}^{2} / 4\right)}
$$

The equation for the surface are of one packing sheet then simplifies into

$$
S_{\text {plate }}=L_{\mathrm{b}} W_{\mathrm{b}}\left[\frac{4(O A) t}{D_{\mathrm{h}}}+2(1-O A)\right]
$$

If $h$ is the plate spacing, and $H_{\mathrm{b}}$ is the total height of the bed, then total plate surface area within the packed bed is given as

$$
S_{\mathrm{p}}=\frac{H_{\mathrm{b}}}{h} L_{\mathrm{b}} W_{\mathrm{b}}\left[\frac{4(O A) t}{D_{\mathrm{h}}}+2(1-O A)\right]
$$

Since the volume of the bed is $L_{\mathrm{b}} W_{\mathrm{b}} H_{\mathrm{b}}$, surface area per unit volume of the packed bed is given by

$$
A_{\text {bed }}^{\prime \prime \prime}=\frac{S_{\mathrm{p}}}{L_{\mathrm{b}} W_{\mathrm{b}} H_{\mathrm{b}}}=\frac{4(O A) t}{h D_{\mathrm{h}}}+\frac{2(1-O A)}{h}
$$

\section{A.2 Calculation of Volume fraction of Electrode}

Volume of $\left(H_{\mathrm{b}} / h\right)$ number of packing sheet plates is given by,

$$
V_{\text {electrode }}=L_{\mathrm{b}} W_{\mathrm{b}} t(1-O A) \frac{H_{\mathrm{b}}}{h}
$$


Volume fraction of Electrode is then given by

$$
\zeta=\frac{V_{\text {electrode }}}{L_{\mathrm{b}} W_{\mathrm{b}} H_{\mathrm{b}}}=\frac{t}{h}(1-O A)
$$

\section{A.3 Calculation of Packed Bed Void Fraction}

The total void volume within the bed is given by

$$
V_{\text {void }}=\left[H_{\mathrm{b}}-\left(\frac{H_{\mathrm{b}}}{h} t\right)\right] W_{\mathrm{b}} L_{\mathrm{b}}+\left(\frac{H_{\mathrm{b}}}{h}\right)\left[\frac{W_{\mathrm{b}} L_{\mathrm{b}}(O A)}{\pi D_{\mathrm{h}}^{2} / 4}\right]\left(\pi D_{\mathrm{h}}^{2} t / 4\right)
$$

The packed bed void fraction, $\epsilon$ can then be calculated as

$$
\epsilon=\frac{V_{\text {void }}}{L_{\mathrm{b}} W_{\mathrm{b}} H_{\mathrm{b}}}=1-\frac{t}{h}[1-(O A)]
$$

\section{A.4 Calculation of equivalent packing diameter}

The equivalent packing diameter is given by,

$$
D_{\mathrm{e}}=\frac{4 \epsilon h}{\frac{4 O A t}{D_{\mathrm{h}}}+2(1-O A)}
$$

\section{A.5 Model for finding carbon surface area per unit volume}

We first assume that the molten salt is entrained with spherical carbon particles. We also assume that the carbon particle flux, $\dot{N}^{\prime \prime}$ (number of carbon particles flowing through the bed per unit area per unit time) will be constant. Now, molar flux of carbon in the salt can be written as

$$
\dot{n}_{\mathrm{C}}^{\prime \prime}=U_{\mathrm{C}} h_{\mathrm{C}} \bar{\rho}_{\mathrm{C}}
$$

where $U_{\mathrm{C}}$ is the downward velocity of the carbon particle, $h_{\mathrm{C}}$ is the carbon holdup within the anode packed bed, and $\bar{\rho}_{\mathrm{C}}$ is the molar density of carbon. The carbon particle flux is given by

$$
\dot{N}^{\prime \prime}=\frac{\dot{n}_{\mathrm{C}}^{\prime \prime}}{n_{\text {part }}}
$$

where $n_{\text {part }}$ is the carbon moles per particle.

At any bed position, $\mathrm{x}$, particle flux is given by,

$$
\dot{N}^{\prime \prime}=\frac{\dot{n}_{\mathrm{C}}^{\prime \prime}(x)}{\bar{\rho}\left(\frac{\pi D_{\mathrm{C}}(x)^{3}}{6}\right)}
$$


which is also equal to the particle flux at the bed start position

$$
\dot{N}^{\prime \prime}=\frac{\dot{n}_{\mathrm{C}, \text { init }}^{\prime \prime}}{\bar{\rho}\left(\frac{\pi D_{\mathrm{C}, \text { init }}^{3}}{6}\right)}
$$

Simplifying equation A.13 and A.14 we get,

$$
D_{\mathrm{C}}(x)=D_{\mathrm{C}, \text { init }}\left(\frac{\dot{n}_{\mathrm{C}}^{\prime \prime}(x)}{\dot{n}_{\mathrm{C}, \text { init }}^{\prime \prime}}\right)^{1 / 3}
$$

If the initial size of the carbon particle and the initial molar flux of carbon is specified and the molar flux of carbon at any bed location $\mathrm{x}$ is known from the solution of the differential equations for the anode bed, then the size of the carbon particle at any $\mathrm{x}$ location within the bed would be easily determined. The initial size of the carbon particle is chosen to be 74 micron found out from the 200 mesh screen sizes provided in [22] on page 9-5.

Now, carbon holdup in general is given by volume of carbon particles per unit volume of the bed.

$$
h_{\mathrm{C}}=V_{\mathrm{C}}^{\prime \prime \prime}=\frac{\text { Volume of Carbon Particles }}{\text { Volume of the Bed }}
$$

The instantaneous carbon holdup with bed position $\mathrm{x}$ can then be written as

$$
h_{\mathrm{C}}(x)=\frac{(\text { Number of Carbon Particles at any } \mathrm{x})\left(V_{\text {part }}(x)\right)}{\text { Volume of the Bed }}=N_{\text {part }}^{\prime \prime \prime}(x) V_{\text {part }}(x)
$$

The reaction surface area of carbon per unit volume of the bed can then be computed from

$$
A_{\text {part }}^{\prime \prime \prime}(x)=N_{\text {part }}^{\prime \prime \prime}(x)\left(\pi D_{\text {part }}^{2}(x)\right)=\frac{h_{\mathrm{C}}(x)}{V_{\text {part }}(x)} \pi D_{\text {part }}^{2}(x)
$$

Simplifying the above equation, the carbon particle area per unit volume of the bed, $A_{\mathrm{s}, \mathrm{a}}^{\prime \prime \prime}$ is given by

$$
A_{\mathrm{C}, \mathrm{a}}^{\prime \prime \prime}(x)=\frac{6 h_{\mathrm{C}}(x)}{D_{\mathrm{c}}(x)}
$$

It should be noted that this equation doesn't take into account the volume fraction of the anode packing material within the bed. So, taking into account the volume fraction of the anode, we get

$$
A_{\mathrm{C}, \mathrm{a}}^{\prime \prime \prime}(x)=\frac{6 h_{\mathrm{C}}(x)}{D_{\mathrm{c}}(x)}\left(1-\zeta_{\mathrm{a}}\right)
$$

where $\zeta_{\mathrm{a}}$ can be computed as in section A.2 given appropriate specifications of the packing 
material in the anode.

\section{B Contact Resistance Model}

\section{B.1 Bed Expansion Evaluation}

Morooka correlation [23] defines E as,

$$
E=\frac{\text { Bed Volume }}{\text { Bed Volume non-fluidized }}
$$

So if we chose carbon for anode from the materials shown in Table A-1, then we realize that on the average $V_{\text {rest }}=1.922-2.50 V_{\text {solid }}$. So, at rest $V \approx E_{\mathrm{r}} V_{\text {solid }}$ where $E_{\mathrm{r}}$ called "Rest Expansion" is approximately 2. Now from the definition of E, we can write

$$
E=\frac{1 / \text { Vol Fract } \mathrm{C}}{1 / \text { Rest Vol Fract C }}=\frac{1 / \text { Vol Fract C }}{V_{\text {tot,rest }} / V_{\text {solid,rest }}}=\frac{1}{\alpha_{\mathrm{s}} E_{\mathrm{r}}}
$$

where $\alpha_{\mathrm{s}}$ is the volume fraction carbon and $E_{\mathrm{r}}$ does not include the fixed bed volume.

Table A-1: Densities of various forms of carbon

\begin{tabular}{llr}
\hline Type of carbon & $\begin{array}{l}\text { Density } \\
\left(\mathrm{kg} / \mathrm{m}^{3}\right)\end{array}$ & Remarks \\
\hline Anthracite & 1554 & Average \\
Bulk Anthracite & 841.5 & Average, size not given \\
Coke & 1201 & \\
Bulk Coke & 441 & Average \\
Charcoal & 481 & Oak \\
Charcoal & 369 & Pine \\
Bulk Charcoal & 192 & Average \\
\hline
\end{tabular}

\section{B.2 Resistivity Correlation}

Resistivity correlation from Morooka [23] can be written as,

$$
\rho_{\mathrm{m}}(\text { in } \Omega \mathrm{m})=0.0004(100 E)^{2}
$$


where $\mathrm{E}$ is as defined above in equation B.2. Simplifying we get,

$$
\rho_{\mathrm{m}}(\text { in } \Omega \mathrm{m})=\frac{1}{\alpha_{\mathrm{s}}^{2}}
$$

We utilize an analogical model from heat transfer to develop a crude model for voltage drop due to contact resistance in the packed bed anode. Solid with internal generation is analogous to solid with "current sources" (ionic current $\leftrightarrow$ electronic current). So for a flat plate with walls at $T_{\mathrm{w}}$, half-thickness $\mathrm{L}$, and conductivity $\mathrm{k}$, the temperature difference relationship is given from [24] as,

$$
T-T_{\mathrm{w}}=\frac{\dot{q}^{\prime \prime \prime}\left(L^{2}-x^{2}\right)}{2 k}
$$

The average relationship can then be computed to be,

$$
T_{\mathrm{avg}}-T_{\mathrm{w}}=\frac{\dot{q}^{\prime \prime \prime}}{2 k} \frac{\int_{0}^{L}\left(L^{2}-x^{2}\right) d x}{L}=\frac{\dot{q}^{\prime \prime \prime} L^{2}}{3 k}
$$

Converting to i instead of $\mathrm{q}, \dot{q}^{\prime \prime \prime}$ becomes $\left(i_{\mathrm{s}}^{\prime \prime} A_{\mathrm{s}}^{\prime \prime \prime}\right)$, k becomes $\left(1 / \rho_{\mathrm{m}}\right)$, and $\left(T_{\mathrm{avg}}-T_{\mathrm{w}}\right)$ becomes $\left(\Delta V_{\mathrm{CR}}\right)$. So we have,

$$
\Delta V_{\mathrm{CR}}=\frac{\rho_{\mathrm{m}} i_{\mathrm{s}}^{\prime \prime} A_{\mathrm{s}}^{\prime \prime \prime} L^{2}}{3}
$$

where $A_{\mathrm{s}}^{\prime \prime \prime}$ is the carbon particle surface area per unit volume. Now, this model is crude because $i_{\mathrm{s}}^{\prime \prime}$ is not constant and is higher when $\Delta V$ is lower.

For 3-D geometry, $(1 / \mathrm{L})$ is equivalent to the area per unit volume $\left(A^{\prime \prime \prime}\right)$. In the case of anode packed bed it's the grid area per unit volume of the bed $\left(A_{\mathrm{g}}^{\prime \prime \prime}\right)$. So, for the drop in the voltage due to contact resistance, we have the following equation

$$
\Delta V_{\mathrm{CR}}=\frac{\rho_{\mathrm{m}} i_{\mathrm{s}}^{\prime \prime} A_{\mathrm{s}}^{\prime \prime \prime}}{3\left(A_{\mathrm{g}}^{\prime \prime \prime}\right)^{2}}
$$

and putting in the expression for $\rho_{\mathrm{m}}$, we get

$$
\Delta V_{\mathrm{CR}}=\frac{i_{\mathrm{s}}^{\prime \prime} A_{\mathrm{s}}^{\prime \prime \prime}}{3\left(A_{\mathrm{g}}^{\prime \prime \prime} \alpha_{\mathrm{s}}\right)^{2}}
$$




\section{Open Circuit Potential}

From the chemical kinetics of cathode and anode packed bed in sections 3.1 and 3.2 respectively, cell analysis can be done. Open circuit voltage, $V_{\text {oc }}$, can be found out from Gibb's Energies of the cell half reactions as given below.

$$
\begin{aligned}
\bar{g}_{\mathrm{c}} & =\bar{h}_{\mathrm{c}}-T \bar{s}_{\mathrm{c}} \\
\bar{g}_{\mathrm{o}_{2}} & =\bar{h}_{\mathrm{o}_{2}}-T \bar{s}_{\mathrm{o}_{2}} \\
\bar{g}_{\mathrm{co} 2} & =\bar{h}_{\mathrm{co}_{2}}-T \bar{s}_{\mathrm{co}_{2}} \\
\Delta \bar{g}_{\mathrm{rxn}} & =\bar{g}_{\mathrm{c}}+\bar{g}_{\mathrm{o}_{2}}+\bar{g}_{\mathrm{co}_{2}}
\end{aligned}
$$

Once the $\Delta \bar{g}$ of the reaction is known, open-circuit potential can be found out from equation C.5.

$$
V_{\mathrm{oc}}=\frac{\Delta \bar{g}}{4 F}
$$




\section{Modified equations in Anode due to presence of both $\mathrm{CO}$ and $\mathrm{CO}_{2}$}

The additional first-order differential equations for the inclusion of $\mathrm{CO}$ in the anode analysis is given as below.

$\mathrm{CO}$ in gas and liquid phase:

$$
\begin{aligned}
\frac{d \dot{n}_{\mathrm{co}, \mathrm{g}, \mathrm{a}}^{\prime \prime}}{d x_{\mathrm{a}}} & =-K_{\mathrm{co}, \mathrm{g}-\ell, \mathrm{a}} A_{\mathrm{B}, \mathrm{co}, \mathrm{a}}^{\prime \prime \prime}\left(\frac{\bar{R} T}{H_{\mathrm{co}}} \bar{\rho}_{\mathrm{co}, \mathrm{g}, \mathrm{a}}-\bar{\rho}_{\mathrm{co}, \ell, \mathrm{a}}\right) \\
\frac{d \dot{n}_{\mathrm{co}, \ell, \mathrm{a}}^{\prime \prime}}{d x_{\mathrm{a}}} & =K_{\mathrm{co}, \mathrm{g}-\ell, \mathrm{a}} A_{\mathrm{B}, \mathrm{co}, \mathrm{a}}^{\prime \prime \prime}\left(\frac{\bar{R} T}{H_{\mathrm{co}}} \bar{\rho}_{\mathrm{co}, \mathrm{g}, \mathrm{a}}-\bar{\rho}_{\mathrm{co}, \ell, \mathrm{a}}\right)+\left(\frac{3}{2 F}\right) A_{\mathrm{C}, \mathrm{a}}^{\prime \prime \prime} i_{\mathrm{s}, \mathrm{a}}^{\prime \prime}
\end{aligned}
$$

The modified velocity of the gas phase is given as:

$$
U_{0 \mathrm{G}}=\left(\dot{n}_{\mathrm{co}, \mathrm{g}, \mathrm{a}}^{\prime \prime}+\dot{n}_{\mathrm{co}_{2}, \mathrm{~g}, \mathrm{a}}^{\prime \prime}\right) \frac{\bar{R} T}{101.325}
$$

where the molar flux of $\mathrm{CO}_{2}\left(\dot{n}_{\mathrm{co}_{2}, \mathrm{~g}, \mathrm{a}}^{\prime \prime}\right)$ and $\mathrm{CO}\left(\dot{n}_{\mathrm{co}, \mathrm{g}, \mathrm{a}}^{\prime \prime}\right)$ in the gas phase, are determined from the simultaneous solution of the differential equations in section 3.2.1 and the additional equations (for $\mathrm{CO})$ as described above. The gas-liquid mass transfer coefficient $\left(K_{\mathrm{co}, \mathrm{L}, \mathrm{a}} A_{\mathrm{B}}^{\prime \prime \prime}\right)$ for $\mathrm{CO}$ can be found easily from the gas properties of $\mathrm{CO}$.

Modified molar densities of $\mathrm{CO}_{2}$ in liquid and gas phase (units of $\mathrm{kmol} / \mathrm{m}^{3}$ ):

$$
\begin{gathered}
\bar{\rho}_{\mathrm{CO}_{2}, \ell, \mathrm{a}}=\left(\frac{\dot{n}_{\mathrm{CO}_{2}, \ell, \mathrm{a}}^{\prime \prime}}{\dot{n}_{\mathrm{co}, \ell, \mathrm{a}}^{\prime \prime}+\dot{n}_{\mathrm{co}, \ell, \mathrm{a}}^{\prime \prime}+\dot{n}_{\ell}^{\prime \prime}}\right) \bar{\rho}_{\mathrm{salt}} \\
\bar{\rho}_{\mathrm{co}, \mathrm{g}, \mathrm{a}}=\left(\frac{\dot{n}_{\mathrm{co}_{2}, \mathrm{~g}, \mathrm{a}}^{\prime \prime}}{\dot{n}_{\mathrm{co}_{2}, \mathrm{~g}, \mathrm{a}}^{\prime \prime}+\dot{n}_{\mathrm{co}, \mathrm{g}, \mathrm{a}}^{\prime \prime}}\right)\left(\frac{101.325}{\bar{R} T}\right)
\end{gathered}
$$

Molar densities of $\mathrm{CO}$ in liquid and gas phase (units of $\mathrm{kmol} / \mathrm{m}^{3}$ ):

$$
\begin{gathered}
\bar{\rho}_{\mathrm{co}, \ell, \mathrm{a}}=\left(\frac{\dot{n}_{\mathrm{co}, \ell, \mathrm{a}}^{\prime \prime}}{\dot{n}_{\mathrm{co}_{2}, \ell, \mathrm{a}}^{\prime \prime}+\dot{n}_{\mathrm{co}, \ell, \mathrm{a}}^{\prime \prime}+\dot{n}_{\ell}^{\prime \prime}}\right) \bar{\rho}_{\mathrm{salt}} \\
\bar{\rho}_{\mathrm{co}, \mathrm{g}, \mathrm{a}}=\left(\frac{\dot{n}_{\mathrm{co}, \mathrm{g}, \mathrm{a}}^{\prime \prime}}{\dot{n}_{\mathrm{co}_{2}, \mathrm{~g}, \mathrm{a}}^{\prime \prime}+\dot{n}_{\mathrm{co}, \mathrm{g}, \mathrm{a}}^{\prime \prime}}\right)\left(\frac{101.325}{\bar{R} T}\right)
\end{gathered}
$$




\section{E Molten Salt Characteristics and Gas Properties vari- ation with Temperature $\mathrm{T}$}

Molar Density of molten salt (in $\mathrm{kmol} / \mathrm{m}^{3}$ ) is given by,

$$
\bar{\rho}_{\text {salt }}=\frac{\rho_{\mathrm{L}}}{M_{\mathrm{L}}}
$$

where $\rho_{\mathrm{L}}$ is the density of the molten salt (in $\mathrm{kg} / \mathrm{m}^{3}$ ) and $M_{\mathrm{L}}$ is the molecular weight of the molten salt (in $\mathrm{kmol} / \mathrm{kg}$ ).

Molar flux of molten salt (in $\mathrm{kmol} / \mathrm{m}^{2}-\mathrm{s}$ ) is given by,

$$
\dot{n}_{\mathrm{L}}^{\prime \prime}=\frac{U_{\mathrm{oL}}}{\bar{\rho}_{\mathrm{salt}}}
$$

Mole fractions of molten salt used in the study and the variations in density $(\rho)$, surface tension $(\gamma)$, viscosity $(\mu)$, and electrical conductance $(\kappa)$ of the molten salt with temperature for different compositions is as given in [25]. The gas properties variation with temperature is referenced from [26]. 


\section{F Energy Balance Paper}

From: Beth Darchi [mailto:DarchiB@asme.org]

Sent: Friday, February 25, 2005 4:21 PM

To: alkorn@vt.edu

Subject: RE: Request for Copyright Permission

Dear Mr. Kornhauser,

It is our pleasure to grant you permission to use ASME paper "Energy Balance for a Direct Carbon Molten Carbonate Fuel Cell," byAlan Kornhauser and Ritesh Agarwal, paper number HT-FED2004-56887, 2004 Heat Transfer/Fluids Engineering Summer Conference, cited in your letter for inclusion as an Appendix to your final report to the USDOE, which funded the research work. If this report is to be reprinted in the future, please contact ASME to request permission for printing. As is customary, we ask that you ensure full acknowledgment of this material, the author(s), and ASME as original publisher on all printed copies being distributed. Many thanks for your interest in ASME publications. Sincerely,

Beth Darchi Copyrights \& Permissions ASME Three Park Avenue New York, NY 10016 P: 212-591-7700 F: 212-591-7292 E: darchib@asme.org 


\section{HT-FED2004-56887}

\section{ENERGY BALANCE FOR A DIRECT CARBON MOLTEN CARBONATE FUEL CELL}

\author{
RITESH AGARWAL \\ VIRGINIA TECH, MECHANICAL ENGINEERING \\ BLACKSBURG, VA 24061-0238, USA \\ Phone: (540) 231-6891 Email: ritesha@vt.edu
}

\section{ABSTRACT}

A novel fuel cell design uses porous bed electrodes. Liquid electrolyte, with fuel and oxidizer entrained, is circulated through the electrodes.

An energy balance has been done for the cell and auxiliaries. The design calls for the $\mathrm{CO}-\mathrm{CO}_{2}$ mixture leaving the anode to be burned to supply an $\mathrm{O}_{2}-\mathrm{N}_{2}-\mathrm{CO}_{2}$ mixture to the cathode. Two heat exchangers are employed: an air preheater cooling the exhaust and a waste heat exchanger cooling the gases entering the cathode.

Results show that $\mathrm{CO} / \mathrm{CO}_{2}$ ratio is the most important parameter for determining performance. For other conditions ideal, plant efficiency varies from $\sim 90 \%$ for pure $\mathrm{CO}_{2}$ to $\sim 20 \%$ for pure $\mathrm{CO}$.

If decoupled from $\mathrm{CO} / \mathrm{CO}_{2}$ ratio, the main effect of increasing cell temperature is to increase heat transfer rate in the air preheater. This is also the main effect of increasing excess air. Decreasing internal cell efficiency lowers power output and increases waste heat rejection.

Keywords: Fuel cell, direct carbon, molten carbonate, energy balance

$\begin{array}{ll}\text { NOMENCLATUR } \\ H & \text { Enthalpy flow per mole carbon in } \\ H H V & \text { Heating value carbon, mole basis } \\ n & \text { Moles per mole carbon in } \\ P, P_{i} & \text { Pressure, partial pressure } \\ Q & \text { Heat transfer per mole carbon in } \\ S & \text { Entropy flow per mole carbon in } \\ T & \text { Cell temperature } \\ T A & \text { Theoretical air } \\ W & \text { Electrical work per mole carbon in } \\ x_{C O 2} & \text { Mole fraction } \mathrm{CO}_{2} \text { leaving anode } \\ \eta & \text { Cell internal efficiency } \\ \text { Subscripts: } & \\ A N & \text { Anode } \\ C A & \text { Cathode }\end{array}$

\author{
ALAN A. KORNHAUSER \\ VIRGINIA TECH, MECHANICAL ENGINEERING \\ BLACKSBURG, VA 24061-0238, USA \\ Phone (540) 231-7064 Email: alkorn@vt.edu

$\begin{array}{ll}\mathrm{CO} 2, \text { etc. } & \text { Species } \\ H X 1 & \text { Air preheater } \\ H X 2 & \text { Waste heat exchanger } \\ R E V & \text { Reversible }\end{array}$

\section{INTRODUCTION}

Modern fuel cell development, with its origins in the space program, has concentrated on compact fuel cell designs in which an immobile electrolyte is contained between porous membrane electrodes. Fuel and oxidizer are supplied to the electrodes on the sides opposite the electrolyte, and all reactions take place on the electrolyte-wetted surfaces of the electrode membrane.

This type of cell design is effective for a compact cell using gaseous fuel, but it has three serious limitations for utility-scale power generation using coal

1. It cannot be used directly with solid fuel.

2. It does not exhibit good economies of scale: a utility power plant would be made up of a large number of small cells.

3. The membrane electrodes are prone to fouling by ash.

Various researchers have proposed alternate designs to bypass these limitations. Weaver et al [1] proposed a plant in which coal would be formed into solid anodes and fed into a molten carbonate melt. Gür and Huggins [2] heated carbon to vaporize it so that it could react on a solid oxide electrolyte. Horita et al [3] built a cell in which carbon powder was mixed with a carbide powder anode in contact with a solid oxide electrolyte. Cooper [4] and his co-workers supplied a paste of carbon fuel granules in a molten salt to the anode grid of a molten carbonate cell. Vutetakis et al [5] oxidized slurries of coal in molten carbonate melts.

The cell investigated here uses porous bed electrodes. Liquid electrolyte, with fuel and oxidizer entrained, is circulated through the electrodes. The concept is based on the work of Vutetakis et al as well as on that of Matsuno et al [6] on porous bed anodes for gas-fueled molten carbonate cells. It also has roots in those industrial electrolysis technologies which use porous bed electrodes [7].

The energy balance presented here is more concerned with the "balance-of-plant" components than with the details of the 
cell itself. It is, in fact, applicable to other types of direct carbon molten carbonate fuel cells. Since there is no work in the open literature presenting energy balances for direct carbon molten carbonate fuel cells, it is of general interest.

\section{FUEL CELL CONCEPT}

In the proposed fuel cell, as shown in Fig. 1, both the anode and the cathode are electrically connected porous beds.

Molten carbonate salt, with particles of carbon entrained, is pumped downward through the anode bed. It reacts with $\mathrm{CO}_{3}{ }^{=}$ ions diffusing from the cathode to form $\mathrm{CO}$ and $\mathrm{CO}_{2}$ while sending electrons to the load. Downward velocity of the salt is adequate to ensure that both carbon particles and evolved gas bubbles are entrained downwards. Salt, evolved gases, and overfed carbon exit the bottom of the anode and gases are separated from the liquid/solid slurry. The slurry is enriched with more carbon and recirculated through the anode, while the evolved gases are used to supply $\mathrm{CO}_{2}$ to the cathode. The arrangement of burner and heat exchangers for this purpose is discussed under "Balance-of-Plant Concept" below.

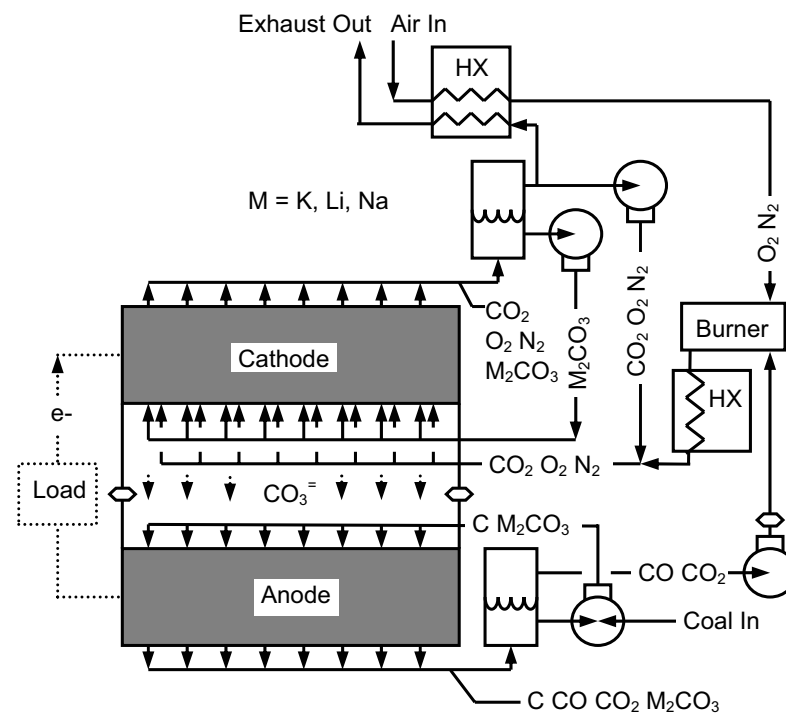

Figure 1. Direct Carbon Molten Carbonate Fuel Cell with Porous Bed Electrodes

Molten carbonate salt is pumped upward through the cathode bed, with $\mathrm{O}_{2}, \mathrm{~N}_{2}$, and $\mathrm{CO}_{2}$ entrained. Some of the $\mathrm{O}_{2}$ and $\mathrm{CO}_{2}$ molecules receive electrons from the load and react to form $\mathrm{CO}_{3}{ }^{=}$ions, which diffuse to the anode. Excess gases exit the top of the anode where they are separated from the liquid. The liquid and part of the gas stream are enriched with more $\mathrm{O}_{2}$ and $\mathrm{CO}_{2}$ and recirculated, while the remainder of the gas stream is exhausted.

Because this cell has a continuous flow of salt through the anode, fuel contaminants will be carried off with the flow. They can then be removed by a sidestream treatment plant such as that described by Weaver et al [8]. Unlike porous-membrane fuel cells, the porous bed cell can be effectively scaled up to large size, so that a utility-scale plant could be made of a relative small number of large cells. The cell is more akin to an electrochemical plant than to a storage battery.

\section{BALANCE-OF-PLANT CONCEPT}

The plant design used for the energy balance is shown schematically in Fig. 2. $\mathrm{CO}$ and $\mathrm{CO}_{2}$ generated in the anode are supplied to a burner, where they are combusted with excess air. The resulting $\mathrm{O}_{2}-\mathrm{N}_{2}-\mathrm{CO}_{2}$ mixture is supplied to the cathode. The air supplied to the burner is preheated by the $\mathrm{N}_{2}, \mathrm{CO}_{2}$, and excess $\mathrm{O}_{2}$ leaving the cathode, and waste heat is recovered from the gases leaving the burner.

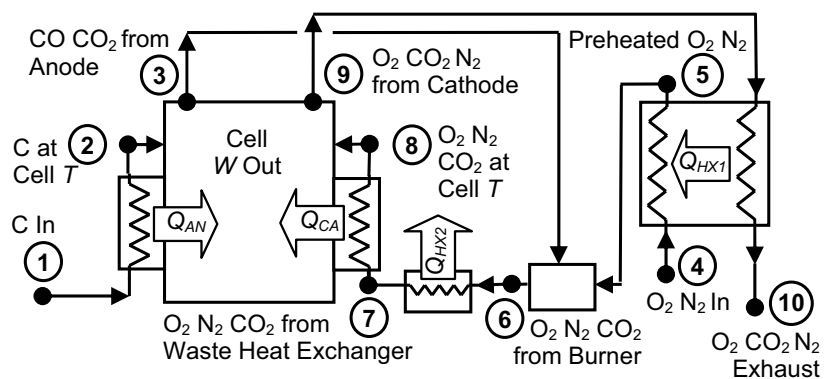

Figure 2. Plant Design for Energy Balance

Two imaginary "heat exchangers" are included in the cell, one to bring the incoming carbon to cell temperature in the anode and the other to bring incoming $\mathrm{O}_{2}-\mathrm{N}_{2}-\mathrm{CO}_{2}$ mixture to cell temperature in the cathode.

The entire plant is assumed to be at atmospheric pressure, and the fuel cell itself is assumed to be at uniform temperature.

\section{MASS BALANCE}

The mass balance is based on the dominant molten carbonate fuel cell reactions. At the anode:

$$
\text { At the cathode: } \begin{gathered}
\mathrm{C}+2 \mathrm{CO}_{3}{ }^{=} \rightarrow 3 \mathrm{CO}_{2}+4 \mathrm{e}^{-} \\
2 \mathrm{C}+\mathrm{CO}_{3}{ }^{=} \rightarrow 3 \mathrm{CO}+2 \mathrm{e}^{-} \\
2 \mathrm{CO}_{2}+\mathrm{O}_{2}+4 \mathrm{e}^{-} \rightarrow 2 \mathrm{CO}_{3}{ }^{=}
\end{gathered}
$$

All balances are done on a "per mole carbon in" basis. The incoming air is assumed to contain 3.76 moles $\mathrm{N}_{2}$ per mole $\mathrm{O}_{2}$ and the incoming fuel is assumed to be pure carbon.

Early workers in direct carbon molten carbonate cells [1] assumed that balance between reaction (1) and reaction (2) at the anode would be determined by the $\mathrm{C}+\mathrm{CO}_{2} \leftrightarrow 2 \mathrm{CO}$ (Boudouard) equilibrium. This would result, for an atmospheric pressure cell, in nearly $100 \% \mathrm{CO}_{2}$ leaving the anode at temperatures below $700 \mathrm{~K}$, a $50-50$ balance at about $950 \mathrm{~K}$, and nearly $100 \% \mathrm{CO}$ at temperatures above $1200 \mathrm{~K}$. Their subsequent work, as well as the work of others $[4,5]$ indicated that $\mathrm{CO}_{2}$ production is dominant at much higher temperatures than predicted by equilibrium.

The mass balance is therefore set up so that $\mathrm{CO}_{2}$ fraction is decoupled from cell temperature. For most cases, the mole fraction $\mathrm{CO}_{2}\left(x_{\mathrm{CO} 2}\right)$ in the gas leaving the anode (node 3 on Fig. 2 ) is fixed. In some cases, for comparison, it is calculated from an approximate expression [1] for the Boudouard equilibrium:

$$
\log _{10}\left[\frac{P_{C O}^{2}}{\left(P_{C O 2}\right)(1 \mathrm{~atm})}\right]=-\frac{8919 \mathrm{~K}}{T}+9.115
$$

Together with $P_{\mathrm{CO} 2}+P_{\mathrm{CO}}=P$ and $x_{\mathrm{CO} 2}=P_{\mathrm{CO} 2} / P$, this expression is used to calculate $x_{\mathrm{CO} 2}$.

Once the composition of the gas leaving the anode is determined, mole balances can be used to calculate the composi- 
tion at all points based on $x_{\mathrm{CO} 2}$ and theoretical air. The results are shown in Table 1.

Table 1. Mole Flows Relative to Mole Flow of Carbon In

\begin{tabular}{|c|c|c|c|c|c|}
\hline \multirow{2}{*}{$\begin{array}{c}\text { Node } \\
\text { (Fig. 2) } \\
\end{array}$} & \multicolumn{5}{|c|}{ Moles per Mole Carbon In } \\
\hline & $\mathrm{C}$ & $\mathrm{O}_{2}$ & $\mathrm{~N}_{2}$ & $\mathrm{CO}$ & $\mathrm{CO}_{2}$ \\
\hline 1,2 & 1 & 0 & 0 & 0 & 0 \\
\hline 3 & 0 & 0 & 0 & $\frac{3-3 x_{\mathrm{CO} 2}}{2-x_{\mathrm{CO} 2}}$ & $\frac{3 x_{\mathrm{CO} 2}}{2-x_{\mathrm{CO} 2}}$ \\
\hline 4,5 & 0 & $T A$ & $3.76 T A$ & 0 & 0 \\
\hline $6,7,8$ & 0 & $T A-\frac{3-3 x_{\mathrm{CO} 2}}{4-2 x_{\mathrm{CO} 2}}$ & $3.76 \mathrm{TA}$ & 0 & $\frac{3}{2-x_{\mathrm{CO} 2}}$ \\
\hline 9,10 & 0 & $T A-1$ & $3.76 T A$ & 0 & 1 \\
\hline
\end{tabular}

\section{ENERGY BALANCE}

Operating conditions for the energy balance are defined by:

- Mole fraction $\mathrm{CO}_{2}$ leaving the anode

- Cell temperature (either equilibrium $T$ or a selected $T$ )

- Fuel and air temperatures

- Minimum $\Delta T$ in the air heater (pinch point is at hot end)

- Fuel cell efficiency relative to a reversible cell.

Enthalpy and entropy flows per mass carbon in are calculated based on the mole flows shown in Table 1 and data tabulated by Gurvich et al [9]. Data are interpolated using a cubic spline technique. Ideal behavior is assumed for all gases.

Some states can be calculated based on the defined temperatures. States of incoming fuel and air (nodes 1 and 4) are based on their known temperatures. States of materials entering and leaving the anode and cathode (nodes 2, 3, 8 and 9) are based on cell temperature. The state of air leaving the preheater (node 5) is based on cell temperature minus the assumed $\Delta T$.

States at the burner exit and of the exhaust (nodes 6 and 10) are calculated from energy balances on the burner and air preheater respectively.

The electrical work output and the state at the waste heat exchanger outlet (node 7) are calculated from energy and entropy balances on the cell. First, a cell that is reversible except for the thermal equilibration of the incoming flows (via $Q_{A N}$ and $\left.Q_{C A}\right)$ is assumed. An energy balance on the carbon entering the cell determines $Q_{A N}$. An entropy balance then gives

$$
Q_{C A, R E V}=T\left(S_{3}+S_{9}-S_{2}-S_{8}\right)-Q_{A N}
$$

and an energy balance gives

$$
W_{R E V}=H_{2}+H_{8}-H_{3}-H_{9}+Q_{A N}+Q_{C A, R E V}
$$

The work for an irreversible cell is then $W=\eta W_{R E V}$ and Eq. (6) is used (without $R E V$ subscripts) to calculate $Q_{C A}$ for the irreversible cell. An energy balance then determines the state at the waste heat exchanger outlet (node 7).

\section{RESULTS}

The mass and energy balances have been performed for a range of operating conditions, all at atmospheric pressure and with fuel and entering at $300 \mathrm{~K}$.

Figure 3 displays non-dimensional work $(W / H H V=$ first law efficiency) and the non-dimensional waste heat $\left(Q_{\mathrm{HX} 2} / H H V\right)$ plotted against $x_{\mathrm{CO} 2}$. Cell $T$ is a parameter, with curves shown for fixed values and also for cell $T$ corresponding to $x_{\mathrm{CO} 2}$ for Boudouard equilibrium. Cell $\eta$ is $100 \%$ and air heater pinch point $\Delta T$ is zero. The plot shows that plant performance is a strong function of $x_{\mathrm{CO} 2}$ and a weaker function of cell $T$. The plot is for stoichiometric air, but the addition of excess air has negligible effect.

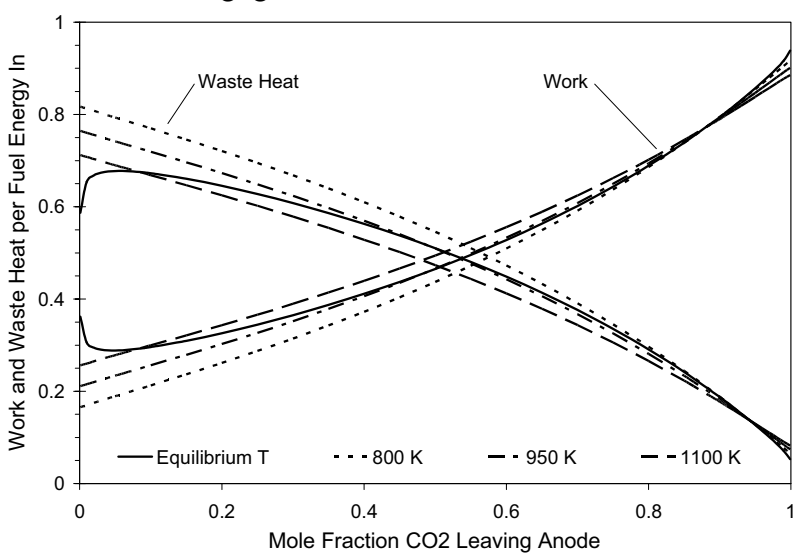

Figure 3. Non-Dimensional Work and Waste Heat vs. Mole Fraction $\mathrm{CO}_{2}$ Leaving Anode, Cell $\mathrm{T}$ as Parameter

Figure 4 also shows non-dimensional work and nondimensional waste heat vs. $x_{\mathrm{CO} 2}$, but with cell internal efficiency as a parameter. As before, air heater pinch point $\Delta T$ is zero and $T A$ is one. Cell $T$ is $950 \mathrm{~K}$. Cell internal $\eta$ variation over the range shown has a greater effect on performance than cell $T$, but its effect is less important than that of $x_{\mathrm{CO} 2}$.

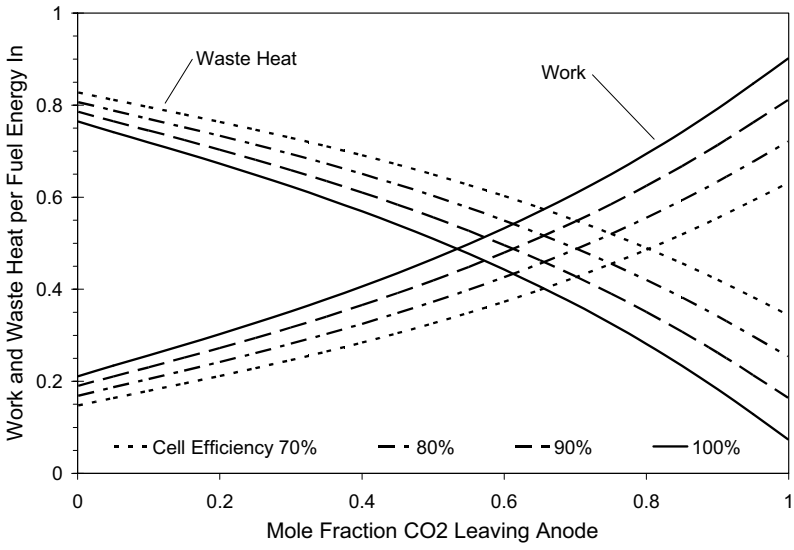

Figure 4. Non-Dimensional Work and Waste Heat vs. Mole Fraction $\mathrm{CO}_{2}$ Leaving Anode, Cell Efficiency as Parameter

Figure 5 displays non-dimensional heat transfer in the air heater $\left(Q_{H X I} / H H V\right)$ as a function of cell temperature with theoretical air as a parameter. Air heater pinch point $\Delta T$ is zero. Cell $\eta$ is $100 \%$ and $x_{\mathrm{CO} 2}$ is the equilibrium value, but variations in these two values would have negligible effect. Also plotted is equilibrium $\mathrm{CO}_{2}$ concentration for the Boudouard equilibrium.

Results are summarized in Table 2.

Since no specific use for the waste heat is planned, it is not possible to evaluate the combined work/waste heat output of the plant. Second-law analysis is not useful unless assumptions are made about temperature differences in the waste heat exchanger. 
The effect of pressure on the mass and energy balances has not been investigated. Such an investigation would require modeling of compressors for incoming air and turbines for outgoing exhaust gases.

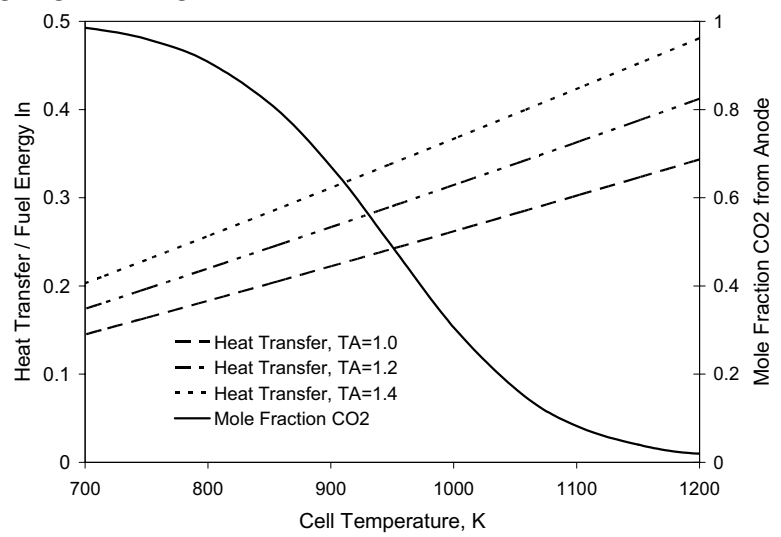

Figure 5. Non-Dimensional Air Heater Heat Transfer and Equilibrium Mole Fraction $\mathrm{CO}_{2}$ Leaving Anode vs. Cell Temperature, Theoretical Air as Parameter

Table 2. Summary of Results

\begin{tabular}{|l|c|c|c|}
\hline \multirow{2}{*}{ Increasing $\uparrow$} & \multicolumn{3}{|c|}{ Effect On } \\
\cline { 2 - 4 } & Work $W$ & Waste Heat $Q$ & Preheater $Q$ \\
\hline $\mathrm{CO}_{2}$ Fraction & Large $\uparrow$ & Large $\downarrow$ & -- \\
\hline $\mathrm{Cell} T^{*}$ & Small $\uparrow * *$ & Small $\downarrow * *$ & Large $\uparrow$ \\
\hline Excess Air & -- & -- & Large $\uparrow$ \\
\hline Cell Efficiency & Medium $\uparrow$ & Medium $\uparrow$ & -- \\
\hline Preheater $\Delta T$ & Small $\downarrow$ & Small $\uparrow$ & Small $\downarrow$ \\
\hline
\end{tabular}

* Independent of $\mathrm{CO}_{2}$ fraction $\quad * *$ Except for $x_{\mathrm{CO} 2} \approx 1$

\section{CONCLUSION}

Results show that that efficiency is determined predominantly by $\mathrm{CO} / \mathrm{CO}_{2}$ ratio leaving the anode. Experiments by others have shown that $\mathrm{CO}_{2}$ concentrations exceed those predicted by Boudouard equilibrium, but a useful alternate model has not been demonstrated. Such a model is clearly necessary for good cell design and accurate prediction of cell performance.

Temperature, if decoupled from $\mathrm{CO} / \mathrm{CO}_{2}$ ratio, has a relatively small effect on first law efficiency. Increasing cell temperature generally increases work output slightly and also increases the value of the waste heat. The most important effects of temperature will likely be those on reaction rates, on materials requirements, and on air preheater size. It may be, for cells of the type described here, that there is considerable temperature difference between the anode and the cathode. Determining this difference will require information on the thermodynamic properties of $\mathrm{CO}_{3}{ }^{\circ}$ in molten salts.

The negligible effect of theoretical air on efficiency is surprising to those accustomed to conventional combustion system design, but is to be expected in a fuel cell plant with effective air preheating. Increased theoretical air will increase preheater size and, in theory, cathode reaction rates.

For the range of cell internal efficiencies (70\%-100\%) studied here, cell internal losses (ohmic losses, overpotential losses, and diffusion losses) are less important than $\mathrm{CO} / \mathrm{CO}_{2}$ balance. For hydrogen-oxygen cells, design has largely been a tradeoff between cell output and cell losses. For direct carbon molten carbonate cells it will apparently be a 3-way tradeoff between losses, output, and $\mathrm{CO} / \mathrm{CO}_{2}$ balance.

Based on the modeling, the cell and plant described here appear to have good potential for utility-scale power production. The chief limitations of the modeling are in the assumption that the cell is isothermal and in the uncertainty of evaluating two parameters $-\mathrm{CO}_{2}$ fraction and cell internal efficiency that lump together many complicated non-idealities.

Further work is needed, including:

- Detailed modeling of processes within the porous bed cell.

- Study of factors affecting the $\mathrm{CO} / \mathrm{CO}_{2}$ balance in direct carbon molten carbonate fuel cells.

- Development of more data on thermodynamic and transport properties in molten carbonate melts.

- Construction of laboratory-scale versions of the porous bed anode and cathode.

Modeling of processes within the porous bed cell is now proceeding at Virginia Tech.

\section{ACKNOWLEDGEMENTS}

The work presented here was supported by the U.S. Department of Energy, University Coal Research Program, and by the Virginia Tech Department of Mechanical Engineering.

\section{REFERENCES}

[1] Weaver, R.D. et al, 1975, "Direct Use of Coal in a Fuel Cell: Feasibility Investigation," EPA-650/2-75-040, U.S. Environmental Protection Agency, Washington, DC.

[2] Gür, T.M. and Huggins, R.A., 1992, "Direct Electrochemical Conversion of Carbon to Electrical Energy in a High Temperature Fuel Cell," Journal of the Electrochemical Society, 139, pp L95-L97.

[3] Horita, T., Sakai, N., Kawada, T., Yokokawa, H., and Dokiya, M., 1995, "An Investigation of Anodes for DirectOxidation of Carbon in Solid Oxide Fuel Cells," Journal of the Electrochemical Society, 142, pp 2621-2624.

[4] Cooper, J.F., 2004, "Direct Conversion of Coal and CoalDerived Carbon in Fuel Cells," Second International Conference on Fuel Cell Science, Engineering, and Technology, Rochester, NY, Paper KH-3.

[5] Vutetakis, D.G., Skidmore, D.R., and Byker, H.J., 1987, "Electrochemical Oxidation of Molten Carbonate-Coal Slurries," Journal of the Electrochemical Society, 134, pp 30273034.

[6] Matsuno, Y., Tsutsumi, A., and Yoshida, K., 1995, "Electrode Performance of Fixed and Fluidized Bed Electrodes for a Molten Carbonate Fuel Cell Anode," International Journal of Hydrogen Energy, 21:8, pp 663-671.

[7] Le Goff, P., Vergnes, F., Coeuret, F., and Bordet, J., 1969, "Applications of Fluidized Beds in Electrochemistry," Industrial and Engineering Chemistry, 61:10, pp 8-17.

[8] Weaver, R.D., Leach, S.C., and Nanis, L., 1981, "Electrolyte Management for the Coal Air Fuel Cell," Proceedings of the $16^{\text {th }}$ Intersociety Energy Conversion Engineering Conference, 1, pp 717-721.

[9] Gurvich, L.V., Veyts, I.V. and Alcock, C.B., 1989, Thermodynamic Properties of Individual Substances, Hemisphere, New York, NY. 


\section{References}

[1] J.F. Cooper, N. Cherepy, R. Upadhye, A. Pasternak, and M. Steinberg. Direct carbon conversion: Review of production and electrochemical conversion of reactive carbons, economics and potential impact on the carbon cycle. Preprint, Lawrence Livermore National Laboratory and Brookhaven National Laboratory, 2000.

[2] M. Steinberg, J.F. Cooper, and N. Cherepy. High efficiency direct carbon and hydrogen fuel cells for fossil fuel power generation. Preprint, Lawrence Livermore National Laboratory and Brookhaven National Laboratory, 2002.

[3] R.D. Weaver, L. Tietz, and D. Cubicciotti. Direct use of coal in a fuel cell: Feasibility investigation. Technical Report EPA-650/2-75-040, SRI International, Menlo Park, California, 1975.

[4] T.M. Gur and R.A. Huggins. Direct electrochemical conversion of carbon to electrical energy in a high temperature fuel cell. Journal of the Electrochemical Society, 139:L95L97, 1992.

[5] T. Horita, N. Sakai, T. Kawada, H. Yokokawa, and M. Dokiya. An investigation of anodes for direct-oxidation of carbon in solid oxide fuel cells. Journal of the Electrochemical Society, 142:2621-2624, 1995.

[6] J.F. Cooper. Direct conversion of coal and coal-derived carbon in fuel cells. In Second International Conference on Fuel Cell Science, Engineering, and Technology, number KH-3, Rochester, NY, 2004.

[7] D.G. Vutetakis, D.R. Skidmore, and H.J. Byker. Electrochemical oxidation of molten carbonate-coal slurries. Journal of the Electrochemical Society, 134:3027-3034, 1987.

[8] P. Le Goff, F. Vergnes, F. Coeuret, and J. Bordet. Applications of fluidized beds in electrochemistry. Industrial and Engineering Chemistry, 61(10):8-17, 1969.

[9] R.D. Weaver, S.C. Leach, and L. Nanis. Electrolyte management for the coal air fuel cell. Proceedings of the 16 th Intersociety Energy Conversion Engineering Conference, 1:717-721, 1981.

[10] R. Agarwal and A.A. Kornhauser. Energy balance for a direct carbon molten carbonate fuel cell. In ASME Heat Transfer / Fluids Engineering Summer Conference, number HT-FED2004-56887, Charlotte, 2004. 
[11] U. Herrmann and G. Emig. Liquid phase hydrogenation of maleic anhydride to 1,4butanediol in a packed bubble column reactor. Ind. Eng. Chem. Res., 37:759-769, 1998.

[12] S.K. Achwal and J.B. Stepanek. Holdup profiles in packed beds. The Chemical Engineering Journal, 12:69-75, 1976.

[13] J.L. Turpin and R.L Huntington. Prediction of pressure drop for two-phase, twocomponent concurrent flow in packed beds. AIChE Journal., 13:1196-1202, 1967.

[14] L.P. Reiss. Cocurrent gas-liquid contacting in packed beds. Ind. Eng. Chem. Proc. Des. Dev., 6:486-499, 1967.

[15] V.A. Kirillov and M.A. Nasamanyan. Mass transfer processes between liquid and packing in a three-phase fixed bed. International Chemical Engineering., 16:538-543, 1976.

[16] Charles W. Tobias. Advances in Electrochemistry and Electrochemical engineering, volume 2. Interscience Publishers, 1966.

[17] G. Wilemski. Simple porous electrode models for molten carbonate fuel cells. J. Electrochem. Soc., 130(1):117-121, 1983.

[18] V. Specchia and G. Baldi. Pressure drop and liquid holdup for two phase concurrent flow in packed beds. Chemical Engineering Science., 32:515-523, 1977.

[19] S.D. Kim, C.G.J. Baker, and M.A. Bergougnou. Hold-up and axial mixing characteristics of two and three phase fluidized beds. The Canadian Journal of Chemical Engineering., 50:695-701, 1972.

[20] Y. Sano, N. Yamaguchi, and T. Adachi. Mass transfer coefficients for suspended particles in agitated vessels and bubble columns. Journal of Chemical Engineering of Japan., 7:255-261, 1974.

[21] R.D. Weaver, S.G. Leach, A.E. Bayce, and L. Nanis. Direct electrochemical generation of electricity from coal. DOE contract EY-76-C-03-0115 P.A. No. 105, SRI International, 1977-79. 
[22] Babcock \& Wilcox, New York, N.Y. 10017. Steam: Its generation and use, 39 edition.

[23] K. Kusakabe, S. Morooka, and Y. Kato. Charge transfer rate in liquid-solid and gasliquid-solid fluidized bed electrodes. Journal of Chemical Engineering of Japan., 14:208$214,1981$.

[24] H.S Carslaw and J.C. Jaeger. Conduction of Heat in Solids. Oxford University Press, 1986.

[25] G.J. Janz, C.B. Allen, N.P. Bansal, R.M. Murphy, and R.P.T. Tomkins. Physical properties data compilations relevant to energy storage. - ii. molten salts: Data on single and multi-component salt systems. National Standard Reference Data System, April 1979.

[26] W.M Kays and M.E. Crawford. Convective Heat and Mass Transfer. McGraw-Hill Book Company, 1980. 